\title{
Does Stakeholder Pressure Matters in Adopting Sustainable Supply Chain Initiatives? Insights from Agro-Based Processing Industry
}

\author{
Tamoor Azam ${ }^{1}$, Songjiang Wang ${ }^{1}$, Muhammad Mohsin ${ }^{2}$, Muhammad Nazam ${ }^{3, * \mathbb{C}}$, Muhammad Hashim ${ }^{4} \mathbb{D}^{\circ}$, \\ Sajjad Ahmad Baig ${ }^{4}$ and Muhammad Zia-ur-Rehman ${ }^{4}{ }^{[}$ \\ 1 Department of Management Sciences and Engineering, School of Management and Economics, \\ Kunming University of Science and Technology, Yunnan 650500, China; tamoorazam@hotmail.com (T.A.); \\ richard777wang@163.com (S.W.) \\ 2 School of Business, Hunan University of Humanities, Science and Technology, Loudi 417000, China; \\ mohsinlatifntu@gmail.com \\ 3 Institute of Business Management Sciences, University of Agriculture, Faisalabad 38000, Pakistan \\ 4 Faisalabad Business School, National Textile University, Faisalabad 37610, Pakistan; \\ hashimscu@gmail.com (M.H.); sajjad.baig@hotmail.com (S.A.B.); zia.msfin@iiu.edu.pk (M.Z.-u.-R.) \\ * Correspondence: muhammad.nazam@uaf.edu.pk; Tel.: +92-331-208-7600
}

\section{check for} updates

Citation: Azam, T.; Wang, S.; Mohsin, M.; Nazam, M.; Hashim, M.; Baig, S.A.; Zia-ur-Rehman, M. Does Stakeholder Pressure Matters in Adopting Sustainable Supply Chain Initiatives? Insights from Agro-Based Processing Industry. Sustainability 2021, 13, 7278. https://doi.org/ $10.3390 /$ su13137278

Academic Editors: Giacomo Falcone and Riccardo Testa

Received: 21 April 2021

Accepted: 23 June 2021

Published: 29 June 2021

Publisher's Note: MDPI stays neutral with regard to jurisdictional claims in published maps and institutional affiliations.

Copyright: (c) 2021 by the authors. Licensee MDPI, Basel, Switzerland. This article is an open access article distributed under the terms and conditions of the Creative Commons Attribution (CC BY) license (https:// creativecommons.org/licenses/by/ $4.0 /)$
Abstract: Over the past few years, sustainable supply chain initiatives (SSCIs) have grabbed attention in the domestic, as well as global, marketplace of the food sector. Nowadays, the success of the entire food supply chain depends on the prosperity of farms, local communities, trader processors, and agrobased industries. Despite its importance, food processing industries (FPIs) are encountering various hurdles in achieving sustainable business goals due to the sheer number of potential barriers. Due to this reason, stakeholders are continuously pressuring the management of FPIs to embrace sustainable food processing activities. In light of this, the present study aims to apply a hybrid fuzzy analytical hierarchy process (F-AHP) framework, based on fuzzy technique for order preference by similarity to the ideal solution (F-TOPSIS), for analyzing the barriers and prioritizing the possible pathways in adopting the SSCIs for the development of FPIs. Based on the extensive review of literature and panel consultation with experienced experts, a total of seven main barriers, forty-two sub barriers, and five possible pathways as strategic tools were finalized and ranked. An empirical case investigation of a Pakistani-based food processing company has been taken to check the practical application of the proposed framework along with sensitivity analysis. The findings of this study reveal that the lack of sustainable outsourcing factors were found as the top-ranked barrier in implementing SSCIs, and the possible pathway to overcome this barrier is the appropriate management of the procurement cycle. The major contribution of this study is to establish a barriers prioritization framework and suggest possible pathways to overcome these barriers for the successful implementation of SSCIs. Finally, the theoretical, managerial, and policy implications are provided as a way forward for the concerned stakeholders and policymakers.

Keywords: barriers; possible pathways; sustainability; fuzzy AHP-TOPSIS; sensitivity analysis

\section{Introduction}

In recent years, immense competition from domestic, as well as global, markets grabbed the attention of industries towards adoption of numerous supply chain initiatives to asseverate the cost gap between the upstream producer and downstream consumers. This bipartite pressure directly influences the performance of manufacturing and service organizations. Hence, the concerned stakeholders insist on applying those supply chain practices, which befit their environment effectively. Among several business practices, the sustainable initiatives emerge to be highly expeditious in terms of improving the operational process and logistics responsiveness of the FPIs. The concept of SSCIs has 
received significant global attention, owing to its capability to enhance the productivity of the business firms [1]. For managing the supply chains efficiently and effectively, the firms should pay attention to applying SSC paradigms to strengthen the sustainability of the organizations in a systematic way [2,3]. The timely implementation of SSCIs related practices in procurement, production, and distribution systems of the FPIs can be helpful in achieving the desired targets of reducing wastages and minimizing the loss of perishable products $[4,5]$. Pakistan, as an agricultural country, continuously strived to enhance the structural improvements in the agri-food industries and formulate the strategies for social, economic, and ecological characteristics. The polluted environment, climate change, and socio-economic constraints are disturbing the limited resources of the industries to operate under an uncertain environment [6]. The social aspect is one of the important aspects to moderate the processes in a supply chain, to influence the labors' health and safety, in line towards community betterment [7]. As the economic aspect concerned, it measures the organizational performance, profitability, and productivity phases of the firms. Due to these socio-economic and environmental aspects, the scope of sustainable business practices are crucial for importers and exporters, as it significantly improves the trade surplus of any economy $[8,9]$.

The supply chain initiatives can be described as a set of activities performed by the firms for smooth functioning of the holistic supply chain system with the socio-economic and environmental needs in a long term period [10]. The sustainable initiatives can also be treated as the significant precondition for achieving the competitive advantages in the current marketplace, globally as well as domestically, in enhancing productivity and profitability of the organizations [11,12]. In the last decade, the term "innovations" referred to waste reduction, solely for the economic perspectives. The environmental and social components did not get much attention and were ignored by the previous researchers. This reason creates attraction for the researchers to search for more opportunities by focusing on the social and environmental perspectives. This specific paradigm changed the holistic direction of research towards sustainability and gained significant recognition [13]. The traditional supply chain management (SCM) practices replaced in favor of the sustainable supply chain management (SSCM) initiatives in most of the Asian industries. The replacement process is not so easy as it encounters certain barriers to eradicate in implementing SSCIs. The conversion process needs a lot of time and empirical work to evaluate the shortcomings of the supply chain system while converting from the traditional (SCM) practices to the sustainable practices [14]. Therefore, most of the food retailers are developing stronger supply chains to attain the competitive advantage by delivering the value to their potential customers.

Nowadays, the adoption of SSCIs is critical for the organization to mitigate risk, handle complexities, and business dynamics of the global outsourcing. For managing supply chains smoothly, it is the very important for industries to integrate supply chains through networks designed for achieving higher business volume [15-17]. This synergistic linking of sustainable supply chain practices moves the organization towards the building of the competitive edge in the global market [18]. No doubt, the domain of adopting sustainable practices is in its initial stages, both theoretically and empirically. Academically, it elaborates the theoretical development processes with logic, practicality, and valid arguments, confirming the applicability of the measurement scales and models [19]. The emphasis should be given to only pay significant attention on applying multiple variables paradigms, assessing their validity and reliability and improving these items using survey-based approaches [20]. Nazam et al. [8] evaluated the risk-oriented model, relevant to (SSCM) in the textile industry of Pakistan, using a hybrid fuzzy multi- criteria AHP-TOPSIS approaches. They suggested that, through the development of an eco-friendly item, the textile firms can be self-sustained not only socially but also economically.

The literature evidences that there is still a major research gap in the field of SSC to analyze it in more accurate ways [21]. In emerging countries perspectives, few research articles are available describing the limited scope of study [22]. The justification 
to implement sustainable initiatives in food processing industries are to accomplish the set performance objectives of the organization [23]. The basic aim of this research is to evaluate the hurdles confronted during adoption of SSCIs and suggest possible pathways to overcome these barriers. The fuzzy logic deals with multi-criteria decision-making $(\mathrm{MCDM})$ related issues under uncertain situations based on different attributes or criterion. The assessment and ranking of the barriers is considered as a MCDM problem, which can be solved by applying the fuzzy logic and tools. Experts, thinking and judging, face uncertain situations while making the decision, due to incomplete or unclear information, and to calculate the exact numerical values. Therefore, in order to overcome the subjectivity and imprecision, the fuzzy logic is the best solution to tackle these problems. This study developed an integrated fuzzy AHP-TOPSIS framework to prioritize barriers in (SSC) and rank possible pathways, using sensitivity analysis, along suitable implications. For this purpose, fuzzy AHP approach is utilized to compute the weights of the barriers by constructing pairwise comparison matrix, and fuzzy TOPSIS, to obtain evaluative inputs of optimal alternatives with triangular fuzzy numbers (TFNs). Studies such as [24,25] elaborated the MCDM models and their applications for solving the SCM related problems in various industries. These approaches suggested the benefits of fuzzy logic approaches over traditional approaches for tackling the uncertain scenarios such as supply chain disruptions, supply chain barriers assessment, and supply chain resilience. Significant numbers of scholars have employed qualitative and quantitative methods such as Fuzzy ANP, Fuzzy ISM, Fuzzy TOPSIS, Fuzzy VIKOR, Fuzzy ELECTRE, Fuzzy PROMETHES, and Multi-objective optimization. Finally, this research developed a proposed framework based on multi-criteria methods. More specifically, this research emphasizes finding the answers of the following three research questions:

RQ1: What type of barriers and possible pathways to the adoption of SSCIs faced by FPIs in the context of Pakistan?

RQ2: Why only a few industries avail benefits from the SSCIs and prioritize the most effective pathways?

RQ3: How the findings would be helpful for industrial stakeholders to develop strategies using fuzzy AHP-TOPSIS approach in achieving business excellence?

This study deals in accomplishing the followings research objectives;

RO1: To identify the key barriers and to select possible pathways for adoption of SSCIs in the FPIs of Pakistan

$\mathrm{RO} 2$ : To analyze the identified barriers and to determine their relative importance using a hybrid fuzzy AHP-TOPSIS approach

RO3: To provide managerial and policy implications regarding adoption of (SSCIs) for the concerned stakeholders.

\subsection{Research Gap}

In the competitive supply chain environment, most food processing industries in Pakistan grasp the significance of barriers faced in achieving the business sustainability in an entire supply chain. Modeling the sustainability-related barriers is a key supply chain function for the sustainable development of any industry. In the developing countries, few number of industries have awareness of business sustainability, and they are eager to adopt the sustainable supply chain strategies for improving their business processes. The inclusion of sustainability in the modern organization is deeply observed by the strategic management such as directors and chief executives officers as a key component to deliver profitability, which has replaced financial cost, value maximization, and responsiveness as the essential topic of discussion among procurement and logistics managers. The success ratio, regarding implementation of sustainable practices, is not so easy due to the presence of many potential barriers. Therefore, this research proposed a sustainability-based framework for filling in this gap and discussing the following issues: (1) FPIs play a dynamic role in the economy of Pakistan; (2) these workplaces are relatively polluted as compared to other types of industries, and the authors observe that this industry creates heavy air 
emissions, wastages, toxicity, and hazardous wastes; (3) the environment is not eco-friendly due to higher level of risk for employees related to the abundance of biological pollutants and physical hazards at the workplace environment. Based on these points, the sustainable development is considering one of the new challenges of Pakistani FPIs. As every country has its own socio-economic and environmental strategies and legislations, a comprehensive research is needed to establish the on sustainability-based framework in a developing country context. In the emerging economy perspective, a major literature gap exists for the eradication of key barriers against SSCIs adoption. In light of this, the present study would be a good attempt to highlight the research gap through a three-phased research tool which comprises Phase 1: Forming an experts group and classifying barriers, Phase 2: Using fuzzy AHP technique to compute the weights vectors of criterion, and Phase 3: Applying fuzzy TOPSIS to rank the alternatives in terms of possible pathways. After the detailed literature review and discussions with experts, forty two barriers were identified, categorized, analyzed, and finally, prioritized.

\subsection{Salient Contributions}

The present study is a toolkit for the managers for providing insights about mutual influences of socio-economic and green perspectives. The contributions of this research deliver a set of implications for appropriate decision-making for improving the sustainability of FPIs. Presently, this study is a toolkit for the industries at the initial stages to improve their supply chain dynamics under the sustainability scenario. This study has the following salient contributions:

- Bridged the gap between academia and industry to understand the essence of sustainable supply chain practices in eradicating the barriers. It also contributed in the literature of fuzzy set theory by introducing the hybrid approach framework.

- Developed an integrated fuzzy AHP-TOPSIS based framework on barriers that influence the adoption of SSCIs.

- Provided empirical insights on sustainable supply chain initiatives, eradication of barriers, and suggesting the possible pathways.

- Conducted a sensitivity analysis, to confirm the accuracy among results, of possible pathways in the FPIs of Pakistan.

- Suggested implications to the concerned stakeholders in improving their supply chain efficiency and effectiveness through sustainable development.

This study is classified into four hierarchical levels as provided in Figure 1. In this diagram, the four level of hierarchical decision processes accomplishes set objectives as follows: Level-(I) Identifying, or exploring, the key barriers to implementing SSCIs in FPIs as an overall goal of the problem under consideration, Level-(II) explaining the classification of main barriers, Level-(III) depicting the type of sub-barriers, and Level (IV) ranking the alternatives as possible pathways. Barriers with sources are explored in Table 1. The remaining part of this study is structured as below. The detailed reviews of previous literature, related to the assessment of barriers in SSC, are discussed in Section 2. In Section 3, the solution approach adopted in this research is discussed step-wise. The proposed framework, based on fuzzy techniques, along with research analysis is presented in Section 4 . The implication of research i.e., managerial, theoretical, and policy are extensively discussed in Section 5. In Section 6, the concluding remarks along limitations and future research directions are summarized. 


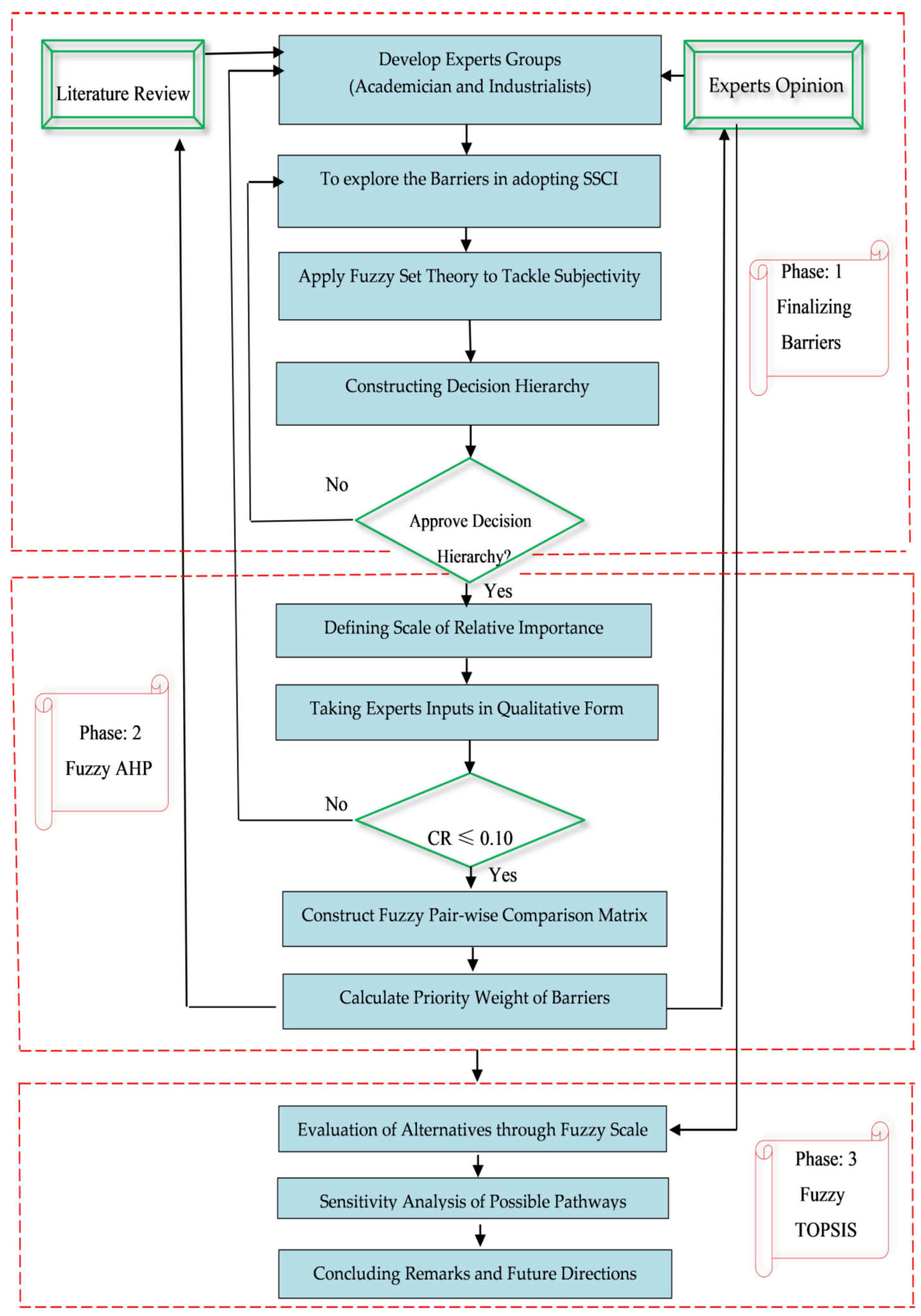

Figure 1. Proposed Hybrid Fuzzy AHP-TOPSIS Framework.

\section{Literature Review}

This section is categorized into three subsections, (2.1) sustainable supply chain initiatives, (2.2) barriers in implementing SSCIs, and (2.3) possible pathways in the existing literature. The explanation of each subsection as follows. 


\subsection{Sustainable Supply Chain Initiatives (SSCI)}

In recent years, the term sustainability has gained popularity and significant attention due to globalization and competitiveness in the food industry [26]. The benefits of adopting sustainable practices in a typical supply chain of food products may generate more valuable creation opportunities, and offer significant food safety, and quality edges in process improvements for organizations. The application of sustainable practices has been taken as a core business issue, as it influences the firm's overall performance. There is a crucial need for combining eco practices in a holistic SSCM.

\subsubsection{Greener Perspectives}

In recent years, the significance of environment consciousness in a food supply chain is getting more popular due to customer demands [27]. In order to achieve the environmental objectives, the manufacturing companies are greatly concerned to adopt greener philosophy in the various stages of supply chain, such as value chain, new product designing, purchase, operations and physical distribution, selling, and advertising of goods and services. Walton [28] emphasized that the companies should develop environment friendly policies while performing the business operations within the stipulated time span smoothly. Chen [29] proposed a model to identify and evaluate the corporate business goals at each level of management in accordance with the greener practices in a supply chain. A lot of environmental factors, domestic, territorial, geographical, global implications, carbon emissions, disposal of wastages, and usage of natural resources, which have to be evaluated and controlled during these growth phases [21]. In this perspective, greener practices are essential to impart the environmental thinking in traditional supply chain management [30].

\subsubsection{Social Perspectives}

The occupational health and safety of workers is linked with the social aspect of supply chain. The social aspect is a very important variable to measure and monitor the level of involvement of the organization with workers' concerns. The corporate social responsibility (CSR) deals with the betterment of workers and organizational performance of the organizations, as it directly affects the productivity of the workers. Hence, the social aspects are considered as the vital elements of the organizations because the survival of most of the firms is based on CSR practices. By applying the concept of CSR, firms can establish an effective working environment in achieving goodwill for the firms in local, as well as international, markets.

\subsubsection{Economic Perspectives}

The integration of financial perspective into the SC network may facilitate boosting the economic performance of the organization to sustain in the global market [31]. The economic aspect is considered a key factor to manage the organizational performance, after social and environmental aspects, because it directly influences the profitability of the firms [32]. In addition, this perspective focus not only on the supply chain optimization but also to maximize the $\mathrm{SC}$ surplus by reducing the procurement cost and cost of production and physical distributions.

\subsection{Overview of Barriers in Implementing SSCIs}

Based on the previous studies and literature, it has been observed that much attention paid on specific areas of SSCIs such as sustainable outsourcing, organizational environment, intrinsic production systems and extrinsic physical distribution system, capabilities and competitiveness, buyer-supplier relationship, marketing management, knowledge creation and dissemination, and technology transfer in the whole supply chain process. Most of the researchers suggest that the SSC related research should shift from the qualitative studies towards empirical and theoretical based approaches in order to tackle the uncertainty in data [33]. The management and prioritization of barriers, while adopting sustainability 
aspects in micro small and medium enterprises (MSMEs), is totally varied from those of large industries in different aspects. Some of the researchers suggested that adoption of SSCIs in SMEs is complicated and not easy to distinguish [34]. Carter and Rogers [12] examined that industries usually flop to implement SSCIs due to certain aspects such as sinking costs, lack of communication structures, departmental politics, organizational culture, and institutional norms. Similarly, Junaid [35] conducted research to explore the sustainable supply chain risk and further integrate supply chain practices in the automotive industry of Pakistan. Nazam et al. [2] evaluated the risk-oriented assessment model against supply chain practices implementation in the textile industry of Pakistan. They further circulated cross-sectional questionnaires to the industrial experts, seeking input through the (FAHP) technique. Rasool et al. [22] evaluated the barriers in adoption of SSCM initiatives in the textile sector of Pakistan and recommended that barriers directly influence the profitability and success ratio of industries. Abbasi [36] analyzed sustainable practices in Pakistani manufacturing supply chains and evaluated critical success factors for SSCM adoption. Mumtaz et al. [3] analyzed the impact of SSC on industrial organizational performance in the manufacturing industries of Pakistan. The literature evident that fewer researches were found to analyze barriers in the adoption of SSCIs in the perspectives of Pakistani industry. However, modeling the barriers is a multi-criteria scenario, which can be addressed by applying (FAHP) methodology in order to tackle the complexity and subjectivity of the variables, considered in the proposed model. For this reason, the (FTOPSIS) approach is also very appropriate in managing real world practical problems under uncertain environment. Based on the review of literature, none of the work has been done for the identification of key barriers in (FPIs) of Pakistan. Similar research studies were attempted by the industries of China, Turkey, Iran, India, and Malaysia [37], but the different industries have the different opinions about SSCIs implementation. The detailed list of barriers identified for implementing SSCIs in FPIs is given in Table 1.

Table 1. List of barriers identified for implementing SSCIs in FPIs.

\begin{tabular}{|c|c|c|c|c|}
\hline Categories of Barriers & Codes & $\begin{array}{c}\text { Key Barriers in Adopting } \\
\text { (SSCI) }\end{array}$ & Brief Descriptions & Sources \\
\hline \multirow{6}{*}{$\begin{array}{c}\text { Sustainable } \\
\text { Outsourcing (SO) }\end{array}$} & $\mathrm{SO}_{1}$ & $\begin{array}{l}\text { Facing problems in maintaining } \\
\text { sustainable suppliers }\end{array}$ & $\begin{array}{l}\text { With sustainability perspective, } \\
\text { industries find it difficult to maintain } \\
\text { sustainable suppliers as the interest of } \\
\text { supplier is different in the entire } \\
\text { supply chain }\end{array}$ & {$[8,34,38,39]$} \\
\hline & $\mathrm{SO}_{2}$ & $\begin{array}{l}\text { Complexity in monitoring } \\
\text { suppliers' eco-practices }\end{array}$ & $\begin{array}{c}\text { Due to conservative managerial styles, } \\
\text { it's difficult mitigate the eco-friendly } \\
\text { practices of suppliers }\end{array}$ & {$[34,40,41]$} \\
\hline & $\mathrm{SO}_{3}$ & $\begin{array}{l}\text { Lack of buyer-supplier } \\
\text { partnerships based on } \\
\text { environmental aspects }\end{array}$ & $\begin{array}{l}\text { Due to lack of compliance and } \\
\text { implementation of ISO 14,001 } \\
\text { standards, firms face challenges to } \\
\text { keep buyer-supplier partnerships }\end{array}$ & [42] \\
\hline & $\mathrm{SO}_{4}$ & $\begin{array}{l}\text { No proper focus of Govt. to } \\
\text { support (SSCI) }\end{array}$ & $\begin{array}{l}\text { Government is not so much concerned } \\
\text { to develop eco-friendly regulations } \\
\text { and policies for industries operating } \\
\text { in special industrial zones }\end{array}$ & [21] \\
\hline & $\mathrm{SO}_{5}$ & $\begin{array}{l}\text { Lack of distinction and } \\
\text { appreciation system for vendors }\end{array}$ & $\begin{array}{l}\text { The industries are silent and not } \\
\text { taking interest to educate the } \\
\text { personnel of suppliers for adopting } \\
\text { sustainable concepts }\end{array}$ & [43] \\
\hline & $\mathrm{SO}_{6}$ & $\begin{array}{l}\text { Trust deficit in maintaining } \\
\text { sustainable relationship with } \\
\text { sustainable supplier }\end{array}$ & $\begin{array}{c}\text { Lack of trust on developing } \\
\text { sustainable relationship with supplier } \\
\text { in long run }\end{array}$ & [30] \\
\hline
\end{tabular}


Table 1. Cont.

\begin{tabular}{|c|c|c|c|c|}
\hline Categories of Barriers & Codes & $\begin{array}{l}\text { Key Barriers in Adopting } \\
\text { (SSCI) }\end{array}$ & Brief Descriptions & Sources \\
\hline \multirow{7}{*}{$\begin{array}{c}\text { Sustainable } \\
\text { Production and } \\
\text { Distribution (SPD) }\end{array}$} & SPD $_{1}$ & $\begin{array}{c}\text { Usage of toxic and polluted raw } \\
\text { material inside the factory } \\
\text { premises }\end{array}$ & $\begin{array}{l}\text { The application of contaminated raw } \\
\text { material in operational process leads } \\
\text { towards the toxic finished product } \\
\text { which eventually decrease the market } \\
\text { value of the product }\end{array}$ & [31] \\
\hline & $\mathrm{SPD}_{2}$ & $\begin{array}{c}\text { Involvement of key } \\
\text { Customers in new product } \\
\text { development }\end{array}$ & $\begin{array}{l}\text { During product development the } \\
\text { inclusion of key customer is crucial in } \\
\text { designing new product }\end{array}$ & {$[44,45]$} \\
\hline & $\mathrm{SPD}_{3}$ & $\begin{array}{l}\text { Adequacy for disposal of the } \\
\text { waste }\end{array}$ & $\begin{array}{l}\text { Industries have no proper drainage } \\
\text { system for disposal of the wastage }\end{array}$ & {$[23,46,47]$} \\
\hline & $\mathrm{SPD}_{4}$ & $\begin{array}{l}\text { Stock availability for performing } \\
\text { the operations in a sustainable } \\
\text { ways }\end{array}$ & $\begin{array}{l}\text { Due to lack of awareness in the } \\
\text { market, producer find it difficult to } \\
\text { arrange contamination free stock for } \\
\text { operational functions }\end{array}$ & [48] \\
\hline & $\mathrm{SPD}_{5}$ & $\begin{array}{l}\text { Waste minimization In } \\
\text { production process }\end{array}$ & $\begin{array}{l}\text { Implementation of lean six sigma } \\
\text { concept can reduce the wastage in } \\
\text { production phase }\end{array}$ & [49] \\
\hline & $\mathrm{SPD}_{6}$ & $\begin{array}{l}\text { Requesting compliance } \\
\text { statements }\end{array}$ & $\begin{array}{l}\text { Organizations are unable to comply } \\
\text { particular rules and regulations set by } \\
\text { the Government bodies and } \\
\text { international authorities }\end{array}$ & [34] \\
\hline & $\mathrm{SPD}_{7}$ & $\begin{array}{l}\text { Lack of flexibility in operations } \\
\text { and production and process }\end{array}$ & $\begin{array}{l}\text { Operational flexibility and production } \\
\text { capacity is poor; still all organization } \\
\text { are not well-integrated } \\
\text { computer-controlled }\end{array}$ & {$[47,50]$} \\
\hline \multirow{4}{*}{$\begin{array}{c}\text { Sustainable } \\
\text { Competitiveness and } \\
\text { Innovation (SCI) }\end{array}$} & $\mathrm{SCI}_{1}$ & $\begin{array}{l}\text { Gain competitive advantage to } \\
\text { keep the competition in market }\end{array}$ & $\begin{array}{l}\text { Industries are facing rapid changes } \\
\text { and competition in the market, due to } \\
\text { the competitive advantage companies } \\
\text { are unable to attract new customers at } \\
\text { a faster rate than its competitors. }\end{array}$ & {$[8,51]$} \\
\hline & $\mathrm{SCI}_{2}$ & $\begin{array}{l}\text { Develop an appropriate } \\
\text { database management system } \\
\text { for maintenance of products }\end{array}$ & $\begin{array}{l}\text { Industries need to struggle for } \\
\text { developing a sustainable database } \\
\text { system for recording of products. } \\
\text { Maintaining highly hazardous } \\
\text { material involves the probability of } \\
\text { financial loss }\end{array}$ & [52] \\
\hline & $\mathrm{SCI}_{3}$ & $\begin{array}{l}\text { Analyzing SSCM practices of } \\
\text { Competitors }\end{array}$ & $\begin{array}{l}\text { Industries are incapable to analyze the } \\
\text { SSCM practices of competitors }\end{array}$ & [53] \\
\hline & $\mathrm{SCI}_{4}$ & $\begin{array}{l}\text { Development of R\&D } \\
\text { Department for research, } \\
\text { innovation and } \\
\text { commercialization of Products }\end{array}$ & $\begin{array}{l}\text { Existing R\&D cell in the industries are } \\
\text { not fully functional; there is a need to } \\
\text { restructure the R\&D cell for } \\
\text { innovation of products }\end{array}$ & {$[2,33,54]$} \\
\hline
\end{tabular}


Table 1. Cont.

\begin{tabular}{|c|c|c|c|c|}
\hline Categories of Barriers & Codes & $\begin{array}{l}\text { Key Barriers in Adopting } \\
\text { (SSCI) }\end{array}$ & Brief Descriptions & Sources \\
\hline \multirow{7}{*}{$\begin{array}{c}\text { Sustainable } \\
\text { Buyer-Supplier } \\
\text { Relationship (SBSR) }\end{array}$} & SBSR $_{1}$ & $\begin{array}{l}\text { Collaborations with buyer and } \\
\text { supplier }\end{array}$ & $\begin{array}{l}\text { With sustainable perspectives, } \\
\text { industries have lack of collaborations } \\
\text { with suppliers }\end{array}$ & {$[55,56]$} \\
\hline & $\mathrm{SBSR}_{2}$ & $\begin{array}{l}\text { Development of supplier of son } \\
\text { on the basis of sustainability } \\
\text { attributes }\end{array}$ & $\begin{array}{c}\text { Lack of awareness of selecting } \\
\text { supplier on the basis of sustainability } \\
\text { attributes }\end{array}$ & [57] \\
\hline & $\mathrm{SBSR}_{3}$ & $\begin{array}{l}\text { Providing awareness to SC } \\
\text { partners for SSCM }\end{array}$ & $\begin{array}{l}\text { Supply chain actors are generally } \\
\text { unaware of sustainable practices }\end{array}$ & [58] \\
\hline & $\mathrm{SBSR}_{4}$ & $\begin{array}{l}\text { Providing access to supplier in } \\
\text { getting design specification }\end{array}$ & $\begin{array}{l}\text { Industries are inefficient to provide } \\
\text { design specification to the supplier }\end{array}$ & [59] \\
\hline & SBSR $_{5}$ & $\begin{array}{l}\text { Perform sustainable } \\
\text { procurement functions in a } \\
\text { supplier context only }\end{array}$ & $\begin{array}{c}\text { Due to lack of sustainable supplier, the } \\
\text { industries are dependent traditional } \\
\text { supplier to procure the hazardous raw } \\
\text { material }\end{array}$ & {$[60]$} \\
\hline & SBSR $_{6}$ & $\begin{array}{l}\text { Provide assurance to deliver } \\
\text { sustainable raw material }\end{array}$ & $\begin{array}{c}\text { Lack of assurance of sustainable raw } \\
\text { material disturb the entire supply } \\
\text { chain }\end{array}$ & {$[61,62]$} \\
\hline & $\mathrm{SBSR}_{7}$ & $\begin{array}{c}\text { Providing rewards } \\
\text { /incentives to buyer and } \\
\text { suppliers }\end{array}$ & $\begin{array}{l}\text { There is no proper reward system } \\
\text { developed by the Govt. bodies. }\end{array}$ & [63] \\
\hline \multirow{7}{*}{$\begin{array}{l}\text { Sustainable } \\
\text { Marketing and } \\
\text { Organizational } \\
\text { Culture (SMOC) }\end{array}$} & $\mathrm{SMOC}_{1}$ & $\begin{array}{l}\text { Providing awareness about } \\
\text { Sustainable products }\end{array}$ & $\begin{array}{l}\text { Lack of awareness about sustainable } \\
\text { products }\end{array}$ & [12] \\
\hline & $\mathrm{SMOC}_{2}$ & $\begin{array}{l}\text { Acquiring customer satisfaction } \\
\text { and loyalty }\end{array}$ & $\begin{array}{l}\text { Facing difficulty to acquire customer } \\
\text { satisfaction and loyalty }\end{array}$ & {$[64]$} \\
\hline & $\mathrm{SMOC}_{3}$ & $\begin{array}{l}\text { Difficulty in finding markets for } \\
\text { sustainable customers }\end{array}$ & $\begin{array}{c}\text { Present industrial mindset and } \\
\text { practices incapable of finding markets } \\
\text { for sustainable customer }\end{array}$ & [65] \\
\hline & $\mathrm{SMOC}_{4}$ & $\begin{array}{l}\text { Complexity in establishing } \\
\text { culture for producing } \\
\text { sustainable products }\end{array}$ & $\begin{array}{l}\text { Industries reluctant to establish } \\
\text { culture for producing sustainable } \\
\text { products }\end{array}$ & {$[66]$} \\
\hline & $\mathrm{SMOC}_{5}$ & $\begin{array}{l}\text { Lack of awareness about } \\
\text { marketing constraints }\end{array}$ & $\begin{array}{c}\text { Market plays a dynamic role towards } \\
\text { sustainable supply chaint; as a } \\
\text { diversified consumer mindset exist in } \\
\text { the market }\end{array}$ & [67] \\
\hline & $\mathrm{SMOC}_{6}$ & $\begin{array}{l}\text { Lack of employees awareness } \\
\text { regarding sustainable practices }\end{array}$ & $\begin{array}{l}\text { Inadequate awareness of employees } \\
\text { about benefits of SSCM practices }\end{array}$ & [68] \\
\hline & $\mathrm{SMOC}_{7}$ & $\begin{array}{l}\text { Providing awareness to } \\
\text { employees about Production } \\
\text { benefits }\end{array}$ & $\begin{array}{l}\text { Inadequate awareness of employees } \\
\text { regarding production benefits of } \\
\text { SSCM practices }\end{array}$ & [69] \\
\hline
\end{tabular}


Table 1. Cont.

\begin{tabular}{|c|c|c|c|c|}
\hline Categories of Barriers & Codes & $\begin{array}{l}\text { Key Barriers in Adopting } \\
\text { (SSCI) }\end{array}$ & Brief Descriptions & Sources \\
\hline \multirow{4}{*}{$\begin{array}{l}\text { SustainableKnowledge } \\
\text { Sharing (SKS) }\end{array}$} & $\mathrm{SKS}_{1}$ & $\begin{array}{l}\text { Sharing awareness regarding } \\
\text { forward and reverse logistics } \\
\text { implementation }\end{array}$ & $\begin{array}{l}\text { Industries are not well aware about } \\
\text { forward and reverse logistics practices } \\
\text { in terms of sustainability }\end{array}$ & {$[70]$} \\
\hline & $\mathrm{SKS}_{2}$ & $\begin{array}{l}\text { Sharing business Information } \\
\text { with Supply chain partners to } \\
\text { avoid disruptions }\end{array}$ & $\begin{array}{l}\text { Facing difficulty in sharing business } \\
\text { information with supply chain actors } \\
\text { to avoid supply chain disruptions }\end{array}$ & [71] \\
\hline & $\mathrm{SKS}_{3}$ & $\begin{array}{l}\text { Difficulty in maximizing the } \\
\text { information sharing process }\end{array}$ & $\begin{array}{l}\text { Supply chain member encounter } \\
\text { difficulties in sharing information of } \\
\text { funds, material and manpower }\end{array}$ & {$[72]$} \\
\hline & $\mathrm{SKS}_{4}$ & $\begin{array}{l}\text { Sharing sustainable supply chain } \\
\text { concepts }\end{array}$ & $\begin{array}{l}\text { Industries lack belief in sharing } \\
\text { sustainable supply chain concepts } \\
\text { within holistic supply chain }\end{array}$ & [73] \\
\hline \multirow{6}{*}{$\begin{array}{c}\text { Sustainable } \\
\text { Technology (ST) }\end{array}$} & $\mathrm{SKS}_{5}$ & $\begin{array}{l}\text { Discouraging disbeliefs about } \\
\text { environmental benefits } \\
\text { Adoption of eco-technology for } \\
\text { producing products }\end{array}$ & $\begin{array}{l}\text { Industries are reluctant to believe on } \\
\text { the ecological benefits of sustainability } \\
\text { Industries face fear in adopting } \\
\text { sustainable supply chain as if } \\
\text { technology fail to implement then it } \\
\text { will create financial loss }\end{array}$ & {$[32,75]$} \\
\hline & $\mathrm{ST}_{2}$ & $\begin{array}{l}\text { Improvement of technological } \\
\text { and cleaner production activities }\end{array}$ & $\begin{array}{l}\text { There is a lack of human resources } \\
\text { and technological capabilities in the } \\
\text { industries }\end{array}$ & {$[14,76]$} \\
\hline & $\mathrm{ST}_{3}$ & $\begin{array}{l}\text { Adoption of technology to } \\
\text { conserve energy consumption }\end{array}$ & $\begin{array}{l}\text { Organizations have not enough } \\
\text { resources to design technology which } \\
\text { reduce energy consumption }\end{array}$ & {$[14,77]$} \\
\hline & $\mathrm{ST}_{4}$ & $\begin{array}{l}\text { Adopting reverse engineering } \\
\text { techniques to design used } \\
\text { products }\end{array}$ & $\begin{array}{c}\text { Inability to design the reuse products } \\
\text { by adopting reverse engineering } \\
\text { technique }\end{array}$ & [78] \\
\hline & $\mathrm{ST}_{5}$ & $\begin{array}{l}\text { Use technical experts to handle } \\
\text { the automation digital activities }\end{array}$ & $\begin{array}{c}\text { Lack of skilled labor to operate the } \\
\text { digital equipment's }\end{array}$ & {$[79,80]$} \\
\hline & $\mathrm{ST}_{6}$ & $\begin{array}{l}\text { Adoption of emerging } \\
\text { technology, Material, } \\
\text { information and process }\end{array}$ & $\begin{array}{l}\text { Employees reluctant to adopt new } \\
\text { technology, material and follow the } \\
\text { process }\end{array}$ & {$[81,82]$} \\
\hline
\end{tabular}

\subsection{Possible Pathways to Implement (SSCIs)}

In the literature, only few studies are available that state the possible pathways as a solution to implement SSCIs in FPIs. A brief piece of discussion about the possible pathways in the light of experts' opinions and literature is as follows:

\subsubsection{Lean Management}

Lean management is a primary pre-requisition to adopt SSCIs in manufacturing and service industries. Lean is the process of eliminating all unessential additional activities and values to improve overall business process [38]. Lean is a process of reducing waste, and it results in cost reduction, better usage of resources, and improvement in quality. Lean management includes the waste minimization in both solid and liquid form. Appropriate lean management of solids and liquids enhances enterprises' performance [39]. The careful management of food wastage, generated from the agri-food industry, acts as a key indicator to maintain balance in the ecosystem.

\subsubsection{Appropriate Infrastructure}

The role of infrastructure acts as a fuel to accelerate the SSCIs adoption process. In order to manage the wastages, proper functions, and industrial processes, it is easier 
due to the availability of suitable infrastructure [40]. As the appropriate infrastructure can facilitate the implementation process of SSCIs in the agri-food industries. Therefore, in the agri-food sector, it must be noted that the infrastructure of the plant or manufacturing facility must be as per biological process of different products and operational functions.

\subsubsection{Sustainable Technology and Techniques}

Sustainable technology and techniques refers to the management of risk and recyclability of materials, conservation of resources, sustainable supply chain practices, and lifecycle of the products. It has been considered as one of the essential possible pathways which moves the industries towards efficiency and effectiveness [41]. In order to adopt SSCIs successfully in FPIs, the adaptation of sustainable technology and techniques are very important to accelerate the industry 4.0 concept.

\subsubsection{Cleaner Production and Recyclability}

This pathway comprises several attributes such as production equipment, techniques, product designs, error free products, and supply chain system [42]. Adoption of cleaner production and recyclability of the products may minimize the adverse reactions of the different type of products on the organizational work environment. This pathway facilitates producing items with less harmful effects through efficient and effective utilization of given resources [43]. The sustainable items could be generated through recycling practices to the greatest possible extent. The adoption of innovative product practices might be accelerating the ecological performance.

\subsubsection{Procurement Management}

Procurement management refers to the management of sourcing processes, suppliers' manufacturing capacities, and awareness about environmental aspects and product innovation [44]. It is one of the most vital pathways in adopting the sustainable supply chain practices in FPIs. The vendor must have awareness of greener practices for satisfying their clients under severe environmental situations [45]. The adaptability of the greener practices between suppliers, firms, and buyers plays a significant role in establishing a competitive advantage [46].

\subsection{Motivation of the Study}

The motivation for performing the current research work is the scarcity of literature in agro-based manufacturing sector of Pakistan, making it a novel work [47]. As with other developing countries, the agriculture sector of Pakistan performs a major role in production of raw materials for the local industry as well as human well-being and development. Pakistan relies heavily on agriculture commodities, which accounts for approximately $19.83 \%$ of the GDP, $43.50 \%$ of the labor workforce, and around $66.23 \%$ of farmers' livelihoods. The studies on food related items such as cereals, biscuits, ketchup, pickles, spices, sauces, and frozen meat have been not explored considering the supply chain process of the food sector in Pakistan. The supply chain of FPIs have unique significance due to two major factors. First, it includes stakeholders that range from suppliers to consumers, who are the main actors in the supply chain of FPIs. Second, the downstream level i.e., customer demand, also severely affects suppliers at the upstream level, which eventually affect the buying and selling process of food items. Keeping in view this context, the stakeholders are continuously pressuring the management of FPIs to embrace sustainable food processing activities [48]. Therefore, FPIs are highly concerned about stakeholders' requirements regarding adoption of sustainable supply chain initiatives. The management of FPIs are under pressure and striving to make compliance of ISO:14001:2004 (Environment Management System) ISO:9001:2015 (Quality Management System) ISO:20400 (Sustainable Procurement) and ISO:26000:2010 (Guidance on Social Responsibility) standards. 


\section{Solution Methodology}

The assessment of the barriers while implementing SSCI is considered as MCDM problem, which can be solved by applying the fuzzy logic and tools. In the real-world organizations, experts judgment face uncertain situations while making the decision among the set of choices due to incomplete information and to calculate the exact numerical values. Therefore, in order to overcome the subjectivity and imprecision the fuzzy logic is the best solution to tackle these problems. Previous studies elaborated the MCDM models, based on applications, for solving the SCM related problems in various industries. The significant numbers of scholars have applied MCDM methods such as Fuzzy ANP, Fuzzy ISM, Fuzzy VIKOR, Fuzzy ELECTRE, Fuzzy PROMETHES, and Multi-objective optimization. In addition, this study developed an integrated fuzzy AHP-TOPSIS framework to prioritize barriers in (SSC) and rank possible pathways using sensitivity analysis along suitable implications. For this purpose, the fuzzy AHP approach is utilized to compute the weights of the barriers by constructing pairwise comparison matrix and fuzzy TOPSIS to obtain evaluative inputs of optimal alternatives with triangular fuzzy numbers (TFNs). This section deals with the modeling phases and systematic approach to design the questionnaire. The proposed research framework is given in Figure 1.

\subsection{Phase 1. Forming the Decision Makers Groups and Classifying Potential Barriers}

Initially, two main groups of decision makers were formed for seeking valuable inputs regarding the identification of barriers. The first group involves the supply chain managers, production managers, and business analysts from all departments of case companies for identification of the barriers being faced by their respective departments through panel discussion. Furthermore, a second team comprised of experts both from academia and industry were also established. A total of three experts (i.e., two from industry and one from academia) were finalized as experts to be approached for making the list of identified barriers and possible pathways, both mutually exclusive and independent. The industrial experts were enriched with experience of 10 and 7 years, respectively, and have awareness in the field of supply chains. The academic expert was an associate professor with sufficient academic subject knowledge and research experience in the discipline of operations, production, physical distribution, and logistics. After extensive review of previous studies and experts' inputs, the categories of barriers confronted in adopting the SSCIs implementation in supply chain was determined.

\subsection{Phase 2. A Glimpse of Fuzzy AHP}

Fuzzy AHP is a relatively flexible decision-making technique, introduced in 1980 by Saaty [24] for solving the complex real life practical problems based on a set of various main criterion and sub-criterion. In this method, the decision makers formulate a set of matrices of different criteria which are to be considered for evaluation. Fuzzy AHP technique utilizes linguistic scales to assess the level of significance of the main criterion with other criterion. After seeking the inputs from experts, a set of pairwise comparison matrices are structured to compute the weight values by taking fuzzy triangular fuzzy numbers (TFNs). Finally, the linguistics values can be transformed into mathematical digits by taking the arithmetic functions. The detailed steps of fuzzy AHP technique are presented as bellows.

Step 1. Determining the scale for evaluation of weights

The nine-point scale of Saaty [24] is utilized to compute weights by applying TFNs and develop the pairwise comparison matrix based on qualitative values as provided in Tables 2 and 3 . The experts take the values from these tables and assign inputs in the form of linguistic expression for computing the criteria weight. The criteria weight shows the intensity of importance of variables under consideration. 
Table 2. Scale for intensity of importance of fuzzy numbers.

\begin{tabular}{cccc}
\hline Scale of Importance & Linguistic Expressions & Triangular Fuzzy Numbers (TFNs) & Reciprocal of TFNs \\
\hline 1 & Equally important (EI) & $(1,1,3)$ & $(0.33,1.00,1.00)$ \\
3 & Weekly important (WI) & $(1,3,5)$ & $(0.20,0.33,1.00)$ \\
5 & Strongly important (SI) & $(3,5,7)$ & $(0.14,0.20,0.33)$ \\
7 & Very strongly important (VSI) & $(5,7,9)$ & $(0.11,0.14,0.20)$ \\
9 & Extremely more important (EMI) & $(7,9,11)$ & $(0.09,0.11,0.14)$ \\
\hline
\end{tabular}

Table 3. Brief profile of academic and industrial experts.

\begin{tabular}{cccc}
\hline Experts & Designation & Experience in Years & Education \\
\hline$X_{1}$ & Associate Professor & 12 & Ph.D. \\
$X_{2}$ & General Manager Production & 10 & B.Sc. \\
$X_{3}$ & Supply Chain Professional & 7 & MBA \\
\hline
\end{tabular}

Step 2. Constructing the fuzzy pairwise comparison matrices

The most important test, known as the consistency test, conducted to check the fuzzy judgment matrices. These matrices are formulated to compute the weight vector of different criterions, which are set as barriers in this study. The TFNs are used to depict the level of importance of the main barrier compared to the sub-barriers, and finally, fuzzy pairwise comparison matrices are formulated for each criteria which is under evaluation process. The scale utilized in formulation of the pairwise comparison matrix in the form of TFNs is provided in Table 2. The consistency ratio (CR) can be calculated by taking (RCI) values to construct pairwise matrix.

Step 3. Computing the weight of criteria and sub-criteria

A questionnaire is circulated among the experts to take necessary inputs in qualitative form or experts' expressions as variables using Table 2. The profile of each expert's experience and qualification is provided in Table 3 . The experts' judgmental values were further converted and analyzed for obtaining the weights vectors of each criterion and subcriterion, which are taken as barriers in this study. The main stages of research methodology adopted in this study are provided in Figure 2.

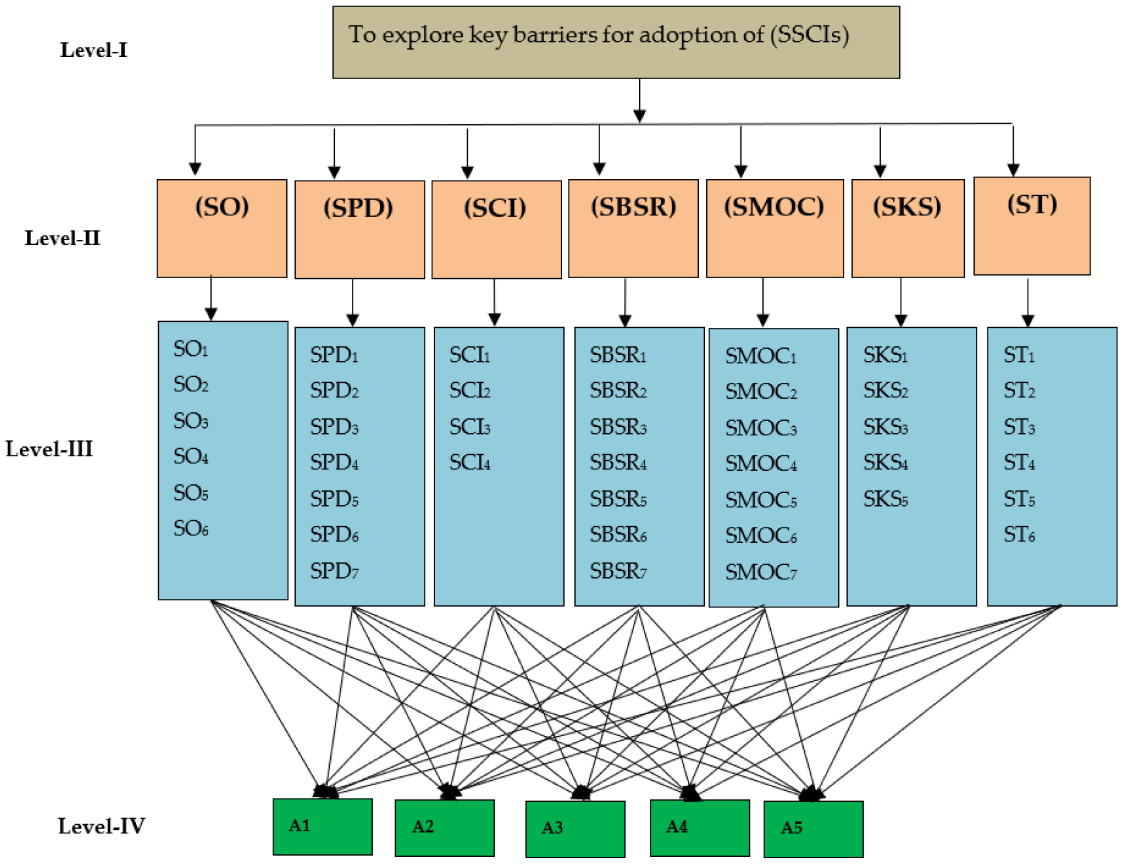

Figure 2. Decision hierarchy of (SSCI) initiatives. 
Step 4. Computing the consistency ratio values

In order to calculate the consistency ratio, first apply the consistency test for checking the level of consistency among criterion. The CR can be computed by taking the detailed steps from this study [83]. Initially, compute the relative weights of criterion and $\lambda_{\mathrm{Max}}$ value for the matrices of order $n$. Then, calculate the final values of CR. The RI value indicates the value of random index, ranging order of matrix. The below mentioned equation is taken to compute the consistency index (CI) for each matrix of order $n$ and also the $\mathrm{CR}$.

$$
\begin{gathered}
\text { Consistency Index }(\mathrm{CI})=(\lambda \max -n) /(n-1) \\
\text { Consistency Ratio }(\mathrm{CR})=\mathrm{CI} / \mathrm{RI}
\end{gathered}
$$

\subsection{Phase 3. Applying Fuzzy Technique for Order Performance by Similarity to Ideal Solution (FTOPSIS)}

The well-known researcher Hwang and Yoon [84] introduced the classical TOPSIS method. The classical TOPSIS described that the selected alternatives in a particular multicriteria decision making problem should have the minimum distance from the positive ideal solution (PIS) and the farthest from the negative ideal solution (NIS). This technique has the classical properties to consider the various criterion with various units taken into account simultaneously [85]. The fuzzy TOPSIS technique is useful for tackling practical MCDM under uncertain conditions. For this purpose, fuzzy set theory, based on fuzzy logic, can be used to present experts' input in the form of linguistic values. Fuzzy TOPSIS technique has been introduced for handling the different MCDM problems of various sectors. Yong [86] applied fuzzy TOPSIS technique for selection of plant location, and Chen [87] applied fuzzy TOPSIS for selecting the supplier. Kahraman [88] used fuzzy TOPSIS for problems related to industrial robotic system selection. Ekmekcioglu [89] utilized the fuzzy TOPSIS method in the selection of municipal solid waste disposal methods. Kutlu and Ekmekcioglu [90] applied a combined fuzzy approach, based on AHP and TOPSIS techniques, to develop a novel failure modes and effects analysis (FMEA) techniques to assess the risk factors for the industries. Kaya and Kahraman [89] formulated a fuzzy TOPSIS-based framework for selecting the ideal energy technology alternatives. Kim [91] proposed fuzzy TOPSIS for developing the model regarding the consumer's product diffusion process. Ertugrul and Karakasoglu [92] performed comparison among MCDM methods by integrating fuzzy AHP-TOPSIS techniques for facility location selection. Nazam [8] developed an integrated risk-oriented assessment model based fuzzy AHP and fuzzy TOPSIS for risk evaluation of GSCM along alternative time window scales in the textile sector of Pakistan.

Step 1: Choosing the qualitative expressions values for the set of alternatives.

Suppose there are $m$ number of set of alternatives taken as possible pathways shown in vector form as $A=\left\{A_{1}, A_{2} \ldots . . A_{m}\right\}$ which can be given inputs in respect to the specified criterion, $C=\left\{C_{1}, C_{2} \ldots \ldots C_{n}\right\}$. The criterion weight values are shown by $w_{j}=$ $\{j=1,2, \ldots \ldots, n\}$. The experts rating $D_{k}\{k=1,2, \ldots \ldots K\}$ for each alternative (known as possible pathways in this study) $A_{i}\{i=1,2, \ldots, m\}$ with respect to criteria (known as barriers in this study) $C_{j}\{j=1,2, \ldots \ldots, n\}$ are shown by membership function. The fuzzy scale adopted for evaluation of alternatives possible pathways is presented in Table 4.

Table 4. The scale for fuzzy evaluation of alternatives.

\begin{tabular}{ccc}
\hline Linguistic Scale & Notations & Corresponding TFNs \\
\hline Very poor & VP & $(1.0,1.0,3.0)$ \\
Poor & P & $(1.0,3.0,5.0)$ \\
Medium & M & $(3.0,5.0,7.0)$ \\
Good & G & $(5.0,7.0,9.0)$ \\
Very good & VG & $(7.0,9.0,11.0)$ \\
\hline
\end{tabular}


Step 2: Calculating aggregated fuzzy ratings for the set of alternatives.

Let us assume that the fuzzy ratings of all experts are depicted as (TFNs) $\widetilde{R}_{k}=\left(a_{k}, b_{k}, c_{k}\right)$, $k=1,2, \ldots, K$ then the aggregated fuzzy rating for the alternative is shown by $\widetilde{R}=(a, b, c)$ $k=1,2, \ldots, K$ where,

$$
a=\min _{k}\left\{a_{k}\right\}, b=\frac{1}{k} \sum_{k=1}^{k} b_{k}, c=\max _{k}\left\{c_{k}\right\}
$$

If the fuzzy rating of the $k$ th decision maker are $\widetilde{X}_{i j k}=\left(a_{i j k}, b_{i j k}, c_{i j k}\right), i=1,2, \ldots m, j=$ $1,2, . ., n$ then the aggregated fuzzy ratings $\widetilde{X}_{i j}$ of alternatives with respect to each criteria are given by $\widetilde{X}_{i j}\left(a_{i j}, b_{i j}, c_{i j}\right)$, where,

$$
a=\min _{k}\left\{a_{i j k}\right\}, b=\frac{1}{k} \sum_{k=1}^{k} b_{i j k}, c=\max _{k}\left\{c_{i j k}\right\}
$$

Step 3: Construct the fuzzy decision matrix for the alternatives.

In this step, the fuzzy decision matrix for the alternatives $(\widetilde{D})$ is formulated as follows:

$$
\widetilde{D}=\left[\begin{array}{c}
A_{1} \\
A_{2} \\
\vdots \\
A_{m}
\end{array}\right]\left[\begin{array}{ccccc}
\widetilde{x}_{11} & \widetilde{x}_{12} & . . & . . & \widetilde{x}_{1 n} \\
\widetilde{x}_{21} & \widetilde{x}_{22} & . . & . . & \widetilde{x}_{2 n} \\
. . & . . & . . & . . & . . \\
. . & . . & . . & . . & . . \\
\widetilde{x}_{m 1} & \widetilde{x}_{m 2} & & & x_{m n}
\end{array}\right] i=1,2, \ldots, m ; j=1,2, \ldots, n
$$

Step 4: Constructing the Normalize fuzzy decision matrix

The experts input in the form of raw data could be normalized by applying linear scale transformation process. The normalized fuzzy decision matrix $\widetilde{R}$ is shown by:

$$
\widetilde{R}=\left[r_{i j}\right]_{m \times n}, i=1,2, \ldots, m ; j=1,2, \ldots, n,
$$

Hence,

$$
\begin{aligned}
& \widetilde{r}_{i j}=\left(\frac{a_{i j}}{c_{j}^{*}}, \frac{b_{i j}}{c_{j}^{*}}, \frac{c_{i j}}{c_{j}^{*}}\right) \text { and } c_{j}^{*}=\max _{i} c_{i j} \text { (benefit criteria) } \\
& \widetilde{r}_{i j}=\left(\frac{a_{j}^{-}}{c_{i j}}, \frac{a_{j}^{-}}{b_{i j}}, \frac{a_{j}^{-}}{a_{i j}}\right) \text { and } a_{j}^{-}=\min _{i} a_{i j} \text { (cost criteria) }
\end{aligned}
$$

Step 5: Constructing the weighted normalized matrix.

In this step, the process of weighted normalized matrix $\left(w_{j}\right)$ for criteria is explained by multiplying the weights $\left(w_{j}\right)$ of evaluation criteria with the normalized fuzzy decision matrix $\widetilde{r}_{i j}$.

$$
\widetilde{V}=\left[v_{i j}\right]_{m \times n} i=1,2, \ldots, \mathrm{m} ; \mathrm{j}=1,2, \ldots, \mathrm{n} \text { where } \widetilde{\mathrm{v}}_{i j}=\widetilde{r}_{i j}(.) W_{j}
$$

Note that $\widetilde{v}_{i j}$ is a TFN represented by $\left(\widetilde{a}_{i j k}, \widetilde{b}_{i j k}, \widetilde{c}_{i j k}\right)$

Step 6: Determining the (FPIS) and (FNIS)

The fuzzy positive ideal solution (FPIS) and fuzzy negative ideal solution (FNIS) of the alternatives can be computed as follows:

$$
\begin{gathered}
A^{*}=\left(\widetilde{v}_{1}^{*}, \widetilde{v}_{2}^{*}, \ldots, \widetilde{v}_{n}^{*}\right) \text { where } \widetilde{v}_{j}^{*}=\left(\widetilde{c}_{j}^{*}, \widetilde{c}_{j}^{*}, \widetilde{c}_{j}^{*}\right) \widetilde{c}_{j}^{*}=\max _{i}\left\{\widetilde{c}_{i j}\right\} \\
A^{-}=\left(\widetilde{v}_{1}^{-}, \widetilde{v}_{2}^{-}, \ldots, \widetilde{v}_{n}^{-}\right) \text {where } \widetilde{v}_{j}^{-}=\left(\widetilde{a}_{j}^{-}, \widetilde{a}_{j}^{-}, \widetilde{a}_{j}^{-}\right) a_{j}^{-}=\min _{i}\left\{\widetilde{a}_{i j}\right\}
\end{gathered}
$$

$i=1,2, \ldots, m ; j=1,2, \ldots, n$

Step 7: Calculate the distance of each alternative from FPIS and FNIS 
The distance $\left(d_{i}^{+}, d_{i}^{-}\right)$of each weighted alternative $I=1,2, \ldots, m$ from the FPIS and the FNIS is calculated as follows:

$$
\begin{aligned}
& d_{i}^{+}=\sum_{j=1}^{n} d v\left(\widetilde{v}_{i j}, \widetilde{v}_{j}^{*}\right), i=1,2, \ldots, m \\
& d_{i}^{-}=\sum_{j=1}^{n} d v\left(\widetilde{v}_{i j}, \widetilde{v}_{j}^{-}\right), i=1,2, \ldots, m
\end{aligned}
$$

Step 8: Calculating the closeness coefficient $C C_{i}$ values.

The closeness coefficient $C C_{i}$ shows the distances to the (FPIS) as $\left(A^{*}\right)$ and the (FNIS) as $\left(A^{-}\right)$simultaneously. Following is the equation to compute the $C C_{i}$ values

$$
C C_{i}=\frac{d_{i}^{-}}{d_{i}^{-}+d_{i}^{+}}
$$

Step 9: Ranking the alternatives and performing a sensitivity analysis

The available set of alternatives are sorted, taking the maximum closeness coefficient $\left(C C_{i}\right)$ values. The values of selected alternatives are chosen in decreasing form or order. For checking the reliability among variables, the sensitivity analysis was conducted to confirm the fluctuation in the $C C_{i}$ values.

\subsection{Scenario of Research Methodology}

This study used food processing industries as a case and applied the proposed methodology, based on FAHP-TOPSIS, to compute the weights intensity level among selected criterion and further rank the most prioritized possible pathways in the supply chain [93-95]. The procedural flow of present research methodology is schematically given in Figure 1 and consists of the following three phases.

Phase 1: Initially, two main groups of decision makers were formed for seeking valuable inputs regarding the identification of barriers [96]. The first group involved the supply chain managers, production managers, and business analysts from all departments of case companies for identification of the barriers being faced by their respective departments through panel discussion [97]. Furthermore, a second team of experts comprised of members from both academia and industry were also constructed. A total of three experts i.e., two from industry (General Manager Production and Supply Chain Professional) and one from academia (Associate Professor) were finalized as experts to be approached for making the list of identified barriers and possible pathways, both mutually exclusive and independent. The industrial experts were enriched with experience of 10 and 7 years, respectively, and have awareness in the field of supply chains. The academic expert was an associate professor with sufficient academic subject knowledge and research experience in the area of production, operations, logistics, and supply chains. In order to accomplish study objectives, a questionnaire was sent to the experts in the relevant field for valuable inputs. The expert selection is definitely critical in a (MCDM) problem. A database was created for the most relevant experts in the (FPIs) of Pakistan, including academicians. Then, from the database, researchers selected the potential experts which were enriched in experience, qualification, and related filed knowledge in the domain of supply chain management. Afterwards, an invitation was sent them to participate in this research. The average number of experts to solve a (MCDM) problem is limited, and most of the studies used three, five, or seven experts in most of the (MCDM) techniques. Therefore, for our convenience we chosen three experts, two from the domain of supply chain management, production management and one from academic sector. The authenticity of chosen number of experts is in accordance with the previous literature on similar type of researchers in different sectors $[3,8,10,53]$. The respondents' brief profiles are presented in Table 3.

Phase 2: In the second phase, the fuzzy AHP approach is applied to compute the weight of criterion. The experts inputs' were converted to the excel sheets for further analysis 
and then weights vectors computed through pairwise comparison matrices. The proposed model was tested through sensitivity analysis, and validated through Excel solver, in order to provide the optimal results. The weight vector of relevant criterion can be derived after making the pairwise comparison matrices by taking the scale provided in Table 2 . The geometric mean of the experts' evaluation computed for establishing the final pairwise comparison matrix to proceed in further steps.

Phase 3: The fuzzy TOPSIS approach is applied to prioritize among the set of possible pathways, proposed to eradicate the barriers confronted in adoption of (SSCI). Linguistic variables and (TFNs) are taken to give score, and further, for the evaluation of alternatives towards the barriers. The ratings of alternatives can be sequentially arranged, based on closeness of coefficients (CC) values computed from fuzzy TOPSIS in descending order.

\section{Proposed Hybrid Fuzzy AHP-TOPSIS Framework}

The main purpose of the present research was to explore the barriers confronted and rate the alternate possible pathways in implementing SSCIs in FPIs.

\subsection{Practical Application of Proposed Framework}

The application of hybrid fuzzy AHP-TOPSIS proposed framework can be classified into five segments: (i) practical scenario of the proposed framework, (ii) taking a survey for finalization of barriers related to the adoption of SSCIs, (iii) using fuzzy AHP for computing the weight of criterion, (iv) category wise results analysis and discussion of results along comparison with existing literature, (v) implications of the research by ranking possible pathways using fuzzy TOPSIS method.

\subsubsection{Phase 1: Taking Survey to Explore the Key Barriers}

This study developed a cross-sectional questionnaire for collecting data from the experts of FPIs and academia in Pakistan. Initially, the questionnaire was circulated among the industrial experts to check the validity of variables. After detailed screening of the questionnaire, the key barriers were determined through applying the fuzzy AHP method.

\subsubsection{Phase 2: Using Fuzzy AHP to Identify Key Barriers for (SSCI) Implementations}

In recent years, the industries of developing countries, such as Pakistan, are experiencing a great deal of business dynamics in sourcing and price fluctuations due to global trends. In this perspective, seven major criterions, consisting of forty two sub-criterions were identified after the detailed discussion with the experts. Participating respondents were asked to provide the pair-wise comparison inputs using Saaty's scale of nine point ranging values, from (1-9), as shown in Table 2. The experts take input from these tables to determine the consistency ratio among the criterion selected. The main criterion weights were computed and provided in Table 5. Thus, the pair-wise comparison matrix of the seven dimensions for the second level and third level of sub-criteria pairwise comparison matrices using AHP technique (see Appendix A, Tables A1-A8). The results summary got from the pairwise comparison matrices are demonstrated in Table 6. The CR of all dimensions are determined to confirm whether the feedbacks provided by experts in calculating the weight vectors are consistent or not. The CR values should not exceed more than 0.1 or $10 \%$ and must be less than 0.1 or $10 \%$ or equal to proceed in further steps. In Table 6, seven major criterions and forty-two sub-criterions along with ratio weights, final weights, and CR values are presented, and the results of this table demonstrate the overall ranking of all sub-criterions in descending order. The results depict that, sustainable outsourcing was found as a highly influencing factor in decision-making of FPIs as the whole supply chain based upon the procurement system. The rest of criterions are also prioritized or sorted in Table 6 and can easily be observed. Outsourcing acts as a crucial barrier for adopting SSCIs in FPIs of Pakistan [38,39]. The sustainable technology barrier category, obtained lower of the weight than sustainable knowledge sharing of the barrier category, thereby showing that industries commonly need more knowledge sharing practices to extend their 
sustainability management systems. Sustainable production and distribution is critical in implementing SSCIs [40,55]. The sustainable competitiveness and innovation barrier category ranks third, whereas the sustainable buyer-supplier relationship ranked fourth The sustainable marketing and organizational culture found at 5th level, which reveals that the strong organizational culture and marketing efforts barrier category are also essential for comparison with other barrier categories.

Table 5. Ranking of categories of major barriers.

\begin{tabular}{ccc}
\hline Barriers Description & Weight Vector & Ratings \\
\hline SO Barriers Dimension & 0.27350 & 1.00 \\
SPD Barriers Dimension & 0.21181 & 2.00 \\
SCI Barriers Dimension & 0.13740 & 4.00 \\
SBSR Barriers Dimension & 0.14251 & 3.00 \\
SMOC Barriers Dimension & 0.08710 & 5.00 \\
SKS Barriers Dimension & 0.08541 & 6.00 \\
ST Barriers Dimension & 0.06220 & 7.00 \\
\hline
\end{tabular}

Table 6. A tabular form of major criteria and sub-criteria with respect to the scenario for (SSCI) in FPIs.

\begin{tabular}{|c|c|c|c|c|c|c|}
\hline Main Criterion & $\begin{array}{l}\text { Main Criterion } \\
\text { Weight }\end{array}$ & Sub-Criteria & $\begin{array}{l}\text { Consistency } \\
\text { Ratio (CR) }\end{array}$ & Ratio Weight & Final Weight & Ratings \\
\hline \multirow{6}{*}{$\begin{array}{l}\text { Sustainable Outsourcing } \\
\text { (SO) }\end{array}$} & \multirow{6}{*}{0.2735} & SO1 & \multirow{6}{*}{0.0640} & 0.3497 & 0.0957 & 1 \\
\hline & & $\mathrm{SO} 2$ & & 0.2410 & 0.0659 & 2 \\
\hline & & $\mathrm{SO} 3$ & & 0.1360 & 0.0372 & 6 \\
\hline & & $\mathrm{SO} 4$ & & 0.1326 & 0.0363 & 9 \\
\hline & & SO5 & & 0.0857 & 0.0234 & 16 \\
\hline & & SO6 & & 0.0550 & 0.0150 & 25 \\
\hline \multirow{7}{*}{$\begin{array}{l}\text { Sustainable Production } \\
\text { and Distribution (SPD) }\end{array}$} & \multirow{7}{*}{0.21181} & SPD1 & \multirow{7}{*}{0.0988} & 0.2692 & 0.0570 & 4 \\
\hline & & SPD2 & & 0.2172 & 0.0460 & 5 \\
\hline & & SPD3 & & 0.1611 & 0.0341 & 12 \\
\hline & & SPD4 & & 0.1322 & 0.0280 & 13 \\
\hline & & SPD5 & & 0.0927 & 0.0196 & 20 \\
\hline & & SPD6 & & 0.0663 & 0.0140 & 28 \\
\hline & & SPD7 & & 0.0612 & 0.0130 & 29 \\
\hline \multirow{4}{*}{$\begin{array}{c}\text { Sustainable } \\
\text { Competitiveness and } \\
\text { Innovation (SCI) }\end{array}$} & \multirow{4}{*}{0.1374} & SCI1 & \multirow{4}{*}{0.0995} & 0.4778 & 0.0658 & 3 \\
\hline & & SCI2 & & 0.2560 & 0.0353 & 11 \\
\hline & & $\mathrm{SCI} 3$ & & 0.1375 & 0.0188 & 22 \\
\hline & & SCI4 & & 0.1283 & 0.0177 & 23 \\
\hline \multirow{7}{*}{$\begin{array}{c}\text { Sustainable Buyer-Supplier } \\
\text { Relationship } \\
\text { (SBSR) }\end{array}$} & \multirow{7}{*}{0.14251} & SBSR1 & \multirow{7}{*}{0.0862} & 0.2493 & 0.0355 & 10 \\
\hline & & SBSR2 & & 0.2574 & 0.0367 & 8 \\
\hline & & SBSR3 & & 0.1701 & 0.0242 & 14 \\
\hline & & SBSR4 & & 0.1138 & 0.0162 & 24 \\
\hline & & SBSR5 & & 0.0986 & 0.0141 & 27 \\
\hline & & SBSR6 & & 0.0549 & 0.0078 & 35 \\
\hline & & SBSR7 & & 0.0559 & 0.0080 & 34 \\
\hline \multirow{7}{*}{$\begin{array}{c}\text { Sustainable Marketing and } \\
\text { Organizational Culture } \\
\text { (SMOC) }\end{array}$} & \multirow{7}{*}{0.0871} & SMOC1 & \multirow{7}{*}{0.0988} & 0.2557 & 0.0223 & 17 \\
\hline & & SMOC2 & & 0.1365 & 0.0119 & 30 \\
\hline & & SMOC3 & & 0.1621 & 0.0141 & 26 \\
\hline & & SMOC4 & & 0.2294 & 0.0200 & 18 \\
\hline & & SMOC5 & & 0.0757 & 0.0066 & 37 \\
\hline & & SMOC6 & & 0.0751 & 0.0065 & 38 \\
\hline & & SMOC7 & & 0.0654 & 0.0057 & 39 \\
\hline
\end{tabular}


Table 6. Cont.

\begin{tabular}{|c|c|c|c|c|c|c|}
\hline Main Criterion & $\begin{array}{c}\text { Main Criterion } \\
\text { Weight }\end{array}$ & Sub-Criteria & $\begin{array}{c}\text { Consistency } \\
\text { Ratio (CR) }\end{array}$ & Ratio Weight & Final Weight & Ratings \\
\hline \multirow{5}{*}{$\begin{array}{c}\text { Sustainable Knowledge } \\
\text { Sharing } \\
\text { (SKS) }\end{array}$} & \multirow{5}{*}{0.08541} & SKS1 & \multirow{5}{*}{0.0901} & 0.2303 & 0.0197 & 19 \\
\hline & & SKS2 & & 0.4301 & 0.0367 & 7 \\
\hline & & SKS3 & & 0.1340 & 0.0114 & 31 \\
\hline & & SKS4 & & 0.1220 & 0.0104 & 32 \\
\hline & & SKS5 & & 0.0836 & 0.0071 & 36 \\
\hline \multirow{6}{*}{$\begin{array}{c}\text { Sustainable Technology } \\
\text { (ST) }\end{array}$} & \multirow{6}{*}{0.0622} & ST1 & \multirow{6}{*}{0.0876} & 0.3060 & 0.019 & 21 \\
\hline & & ST2 & & 0.1630 & 0.0101 & 33 \\
\hline & & ST3 & & 0.0357 & 0.0022 & 42 \\
\hline & & ST4 & & 0.3837 & 0.0239 & 15 \\
\hline & & ST5 & & 0.0696 & 0.0043 & 40 \\
\hline & & ST6 & & 0.0420 & 0.0026 & 41 \\
\hline
\end{tabular}

4.1.3. Phase 3: Results Analysis of Alternatives Possible Pathways Using Fuzzy TOPSIS Approach

In phase 3, the results analysis of alternative possible pathways, using fuzzy TOPSIS technique, conducted to prioritize these alternatives by calculating the $C_{i}$ values in descending order to achieve the selected objectives [98]. The decision makers were requested to formulate a fuzzy evaluation matrix, for the adoption of SSCIs, by applying triangle linguistic variables (See Table 7). That table is developed by making comparison with the alternate possible pathways under consideration of the each criterion separately. Afterwards, transformed linguistic value into relevant TFNs and formulated the fuzzy evaluation matrix for the adoption of SSCIs (See Table 8). The fuzzy aggregated decision matrix of the possible pathways are determined by applying (Equations (1) and (2)) and also given in Table 9. The entire criterions are the barriers of SSCIs, therefore, all the hurdles/challenges treated as the cost criterion and normalization process, are conducted by (Equations (3)-(6)) and for more details, please see Table 10. The fuzzy weighted evaluation matrix can be constructed in the next step for the adoption of SSCIs [99,100]. The weights obtained through fuzzy AHP calculations are used to construct the weighted evaluation matrix and are formulated by using the (Equation (7)), as provided in Table 11.

Table 7. Experts' evaluation of each criterion with respect to alternatives.

\begin{tabular}{|c|c|c|c|c|c|c|c|c|c|c|c|c|}
\hline Sub-Criterion & $\mathrm{SO}_{1}$ & & & $\mathrm{SO}_{2}$ & & & $\mathrm{ST}_{5}$ & & & $\mathrm{ST}_{6}$ & & \\
\hline Experts & DM1 & DM2 & DM3 & DM1 & DM2 & DM3 & DM1 & DM2 & DM3 & DM1 & DM2 & DM3 \\
\hline $\mathrm{A}_{1}$ & G & $M$ & VP & VP & $\mathrm{P}$ & $\mathrm{M}$ & VP & $\mathrm{P}$ & $M$ & $\mathrm{VP}$ & $M$ & $\mathrm{P}$ \\
\hline $\mathrm{A}_{2}$ & VP & $\mathrm{P}$ & $\mathrm{M}$ & $\mathrm{M}$ & VP & VP & VG & M & $\mathrm{P}$ & VG & G & VP \\
\hline $\mathrm{A}_{3}$ & $\mathrm{M}$ & G & $\mathrm{P}$ & M & G & $\mathrm{M}$ & $\mathrm{P}$ & G & G & $\mathrm{P}$ & $\mathrm{P}$ & G \\
\hline $\mathrm{A}_{4}$ & $\mathrm{P}$ & VP & VP & $\mathrm{P}$ & M & $\mathrm{P}$ & $\mathrm{G}$ & VP & VP & M & VP & $\mathrm{M}$ \\
\hline $\mathrm{A}_{5}$ & VG & M & VP & G & VG & G & M & $\mathrm{M}$ & VG & G & VG & VG \\
\hline
\end{tabular}

Table 8. Fuzzy evaluation matrix for the adoption of (SSCI).

\begin{tabular}{ccccccccccccc}
\hline & SO $_{1}$ & & \multicolumn{3}{c}{ SO $_{2}$} & & & ST $_{\mathbf{5}}$ & & \multicolumn{3}{c}{ ST $_{\mathbf{6}}$} \\
\hline & DM1 & DM2 & DM3 & DM1 & DM2 & DM3 & DM1 & DM2 & DM3 & DM1 & DM2 & DM3 \\
\hline $\mathrm{A}_{1}$ & $(5,7,9)$ & $(3,5,7)$ & $(1,1,3)$ & $(1,1,3)$ & $(1,3,5)$ & $(3,5,7)$ & $(1,1,3)$ & $(1,3,5)$ & $(3,5,7)$ & $(1,1,3)$ & $(3,5,7)$ & $(1,3,5)$ \\
$\mathrm{A}_{2}$ & $(1,1,3)$ & $(1,3,5)$ & $(3,5,7)$ & $(3,5,7)$ & $(1,1,3)$ & $(1,1,3)$ & $(7,9,11)$ & $(3,5,7)$ & $(1,3,5)$ & $(7,9,11)$ & $(5,7,9)$ & $(1,1,3)$ \\
$\mathrm{A}_{3}$ & $(3,5,7)$ & $(5,7,9)$ & $(1,3,5)$ & $(3,5,7)$ & $(5,7,9)$ & $(3,5,7)$ & $(1,3,5)$ & $(5,7,9)$ & $(5,7,9)$ & $(1,3,5)$ & $(1,3,5)$ & $(5,7,9)$ \\
$\mathrm{A}_{4}$ & $(1,1,3)$ & $(1,1,3)$ & $(1,1,3)$ & $(1,3,5)$ & $(3,5,7)$ & $(1,3,5)$ & $(5,7,9)$ & $(1,1,3)$ & $(1,1,3)$ & $(3,5,7)$ & $(1,1,3)$ & $(3,5,7)$ \\
$\mathrm{A}_{5}$ & $(7,9,11)$ & $(5,7,9)$ & $(1,1,3)$ & $(5,7,9)$ & $(7,9,11)$ & $(5,7,9)$ & $(3,5,7)$ & $(3,5,7)$ & $(7,9,11)$ & $(5,7,9)$ & $(7,9,11)$ & $(7,9,11)$ \\
\hline
\end{tabular}


Table 9. Fuzzy aggregated decision matrix for the adoption of (SSCI).

\begin{tabular}{ccccccc}
\hline & $\mathbf{S O}_{\mathbf{1}}$ & $\mathbf{S O}_{\mathbf{2}}$ & $\ldots$ & $\ldots$ & $\mathbf{S T}_{\mathbf{5}}$ & $\mathbf{S T}_{\mathbf{6}}$ \\
\hline $\mathrm{A}_{1}$ & $(1.00,4.33,9.00)$ & $(1.00,3.00,7.00)$ & $\ldots$ & $\ldots$ & $(1.00,3.00,7.00)$ & $(1.00,3.00,7.00)$ \\
$\mathrm{A}_{2}$ & $(1.00,3.00,7.00)$ & $(1.00,2.33,7.00)$ & $\ldots$ & $\ldots$ & $(1.00,5.66,11.0)$ & $(1.00,5.66,11.0)$ \\
$\mathrm{A}_{3}$ & $(1.00,5.00,9.00)$ & $(3.00,5.66,9.00)$ & $\ldots$ & $\ldots$ & $(1.00,5.66,9.00)$ & $(1.00,4.33,9.00)$ \\
$\mathrm{A}_{4}$ & $(1.00,1.66,5.00)$ & $(1.00,3.66,7.00)$ & $\ldots$ & $\ldots$ & $(1.00,3.00,9.00)$ & $(1.00,3.66,7.00)$ \\
$\mathrm{A}_{5}$ & $(1.00,5.00,11.00)$ & $(5.00,7.66,11.00)$ & $\ldots$ & $\ldots$ & $(3.00,6.33,11.00)$ & $(5.00,8.33,11.0)$ \\
\hline
\end{tabular}

Table 10. Fuzzy normalized decision matrix for the adoption of (SSCI).

\begin{tabular}{cccccc}
\hline & $\mathbf{S O}_{\mathbf{1}}$ & $\mathbf{S O}_{\mathbf{2}}$ & $\ldots$ & $\mathbf{S T}_{\mathbf{5}}$ & $\mathbf{S T}_{\mathbf{6}}$ \\
\hline $\mathrm{A}_{1}$ & $(0.11,0.23,1.00)$ & $(0.14,0.33,1.00)$ & $\ldots$ & $(0.14,0.33,1.00)$ & $(0.14,0.33,1.00)$ \\
$\mathrm{A}_{2}$ & $(0.14,0.33,1.00)$ & $(0.14,0.42,1.00)$ & $\ldots$ & $(0.09,0.17,1.00)$ & $(0.09,0.17,1.00)$ \\
$\mathrm{A}_{3}$ & $(0.11,0.20,1.00)$ & $(0.11,0.17,0.33)$ & $\ldots$ & $(0.11,0.17,1.00)$ & $(0.11,0.23,1.00)$ \\
$\mathrm{A}_{4}$ & $(0.20,0.60,1.00)$ & $(0.14,0.27,1.00)$ & $\ldots$ & $(0.11,0.33,1.00)$ & $(0.14,0.27,1.00)$ \\
$\mathrm{A}_{5}$ & $(0.09,0.20,1.00)$ & $(0.09,0.13,0.20)$ & $\ldots$ & $(0.09,0.15,0.33)$ & $(0.09,0.12,0.20)$ \\
\hline
\end{tabular}

Table 11. Construction of Weighted normalized fuzzy decision matrix for the adoption of (SSCI).

\begin{tabular}{ccccc}
\hline & SO $_{\mathbf{1}}$ & $\mathbf{S O}_{\mathbf{2}}$ & $\mathbf{S T}_{\mathbf{5}}$ & $\mathbf{S T}_{\mathbf{6}}$ \\
\hline $\mathrm{A}_{1}$ & $(0.0699,0.1499,0.3497)$ & $(0.04821,0.1446,0.2410)$ & $(0.0077,0.0161,0.0696)$ & $(0.0060,0.0140,0.0420)$ \\
$\mathrm{A}_{2}$ & $(0.0500,0.1499,0.3497)$ & $(0.0344,0.0657,0.2410)$ & $(0.0099,0.0161,0.0696)$ & $(0.0084,0.0180,0.0420)$ \\
$\mathrm{A}_{3}$ & $(0.0318,0.0500,0.1166)$ & $(0.0219,0.0314,0.0482)$ & $(0.0099,0.0190,0.0696)$ & $(0.0038,0.0084,0.0420)$ \\
$\mathrm{A}_{4}$ & $(0.0500,0.1166,0.3497)$ & $(0.0344,0.0657,0.2410)$ & $(0.0063,0.0161,0.0696)$ & $(0.0038,0.0060,0.0140)$ \\
$\mathrm{A}_{5}$ & $(0.0389,0.0807,0.3497)$ & $(0.0268,0.0425,0.0803)$ & $(0.0063,0.0099,0.0232)$ & $(0.0038,0.0055,0.0084)$ \\
\hline
\end{tabular}

In this research study, the entire criterions are to be taken as the cost criteria. In this scenario, (FPIS, $A^{*}$ ) and (FNIS, $\left.A^{-}\right)$as $\widetilde{v}^{*}=(0,0,0)$ and $\widetilde{v}^{-}=(1,1,1)$ used as a given sub-criterion. The given sub-criterion are treated as barriers and therefore, they are treated as cost criterion. Afterwards, calculate the distance $d_{v}$ of selected alternatives form FPIS $\left(A^{*}\right)$ and FNIS $\left(A^{-}\right)$taking the (Equations (10) and (11)). Let us take an example in this study, the distance $d_{v}\left(A_{1}, A^{*}\right)$ and $d_{v}\left(A_{1}, A^{-}\right)$for selected possible pathways (alternative) $\mathrm{A}_{1}$ and sub-criteria $\mathrm{M}_{1}$ from FPIS $\left(A^{*}\right)$ and FNIS $\left(A^{-}\right)$. Following the procedure of (Equations (8)-(11)), similar type of computations can be performed for the reset of subcriterion for sorting of possible pathways $\mathrm{A}_{1}$ and computed the overall distances of $d_{i}^{+}$ and $d_{i}^{-}$as $d_{i}^{+}=4.7886$ and $d_{i}^{-}=38.6218$, by taking the (Equation (12)) the $\left(C C_{i}\right)$ values of alternative $A_{1}$. Similar steps can be implemented to calculate the distances and $\left(C C_{i}\right)$ values of rest of the possible pathways. The values obtained through fuzzy TOPSIS are final results are abridged in Table 12. The final ratings of the possible pathways can be arranged on the basis of $\left(C C_{i}\right)$ values sequentially in descending order.

$$
\begin{gathered}
d_{v}\left(A_{1}, A^{+}\right)=\sqrt{\frac{1}{3}\left[(0-0.0699)^{2}+(0-0.1499)^{2}+(0-0.3497)^{2}\right]} \\
d_{v}\left(A_{1}, A^{+}\right)=0.2233 \\
d_{v}\left(A_{1}, A^{-}\right)=\sqrt{\frac{1}{3}\left[(1-0.0699)^{2}+(1-0.1499)^{2}+(1-0.3497)^{2}\right]} \\
C C_{i}=\frac{d_{v}\left(A_{1}, A^{-}\right)=0.8186}{d_{i}^{-}+d_{i}^{+}}=\frac{38.6218}{38.6218+4.7886} \\
C C_{i}=0.8897
\end{gathered}
$$


Table 12. Final ranking of possible pathways for the adoption of (SSCI) based on FTOPSIS.

\begin{tabular}{ccccc}
\hline Pathways & $\boldsymbol{d}_{\boldsymbol{i}}^{+}$ & $\boldsymbol{d}_{\boldsymbol{i}}^{-}$ & $\boldsymbol{C} \boldsymbol{C}_{\boldsymbol{i}}$ & Rank \\
\hline $\mathbf{A}_{\mathbf{1}}$ & 4.7886 & 38.6218 & 0.8897 & 5 \\
$\mathbf{A}_{\mathbf{2}}$ & 4.7443 & 38.6049 & 0.8906 & 4 \\
$\mathbf{A}_{\mathbf{3}}$ & 4.3526 & 39.1451 & 0.8999 & 3 \\
$\mathbf{A}_{\mathbf{4}}$ & 4.2467 & 38.9870 & 0.9018 & 2 \\
$\mathbf{A}_{\mathbf{5}}$ & 1.7196 & 40.6442 & 0.9594 & 1 \\
\hline
\end{tabular}

The closeness of the coefficient and final ranking of the possible pathways, shown in Figure 3, were analyzed by making comparison with sub-criterion. To rank the alternatives for adoption of the sustainable supply chain initiatives are calculated taking fuzzy TOPSIS technique. The ranking of alternatives is obtained, using steps of fuzzy TOPSIS method and shown the values of $C C_{i}$ in Table 12. The possible pathways are prioritized in descending order. Finally, the findings depict that $\mathrm{A}_{5}$ got the highest $C C_{i}$ value. Therefore, considering the values of $\mathrm{CC}_{i}$, the prioritization among alternatives can be observed as: $\mathrm{A} 5>\mathrm{A} 4>\mathrm{A} 3>$ A2 > A1.

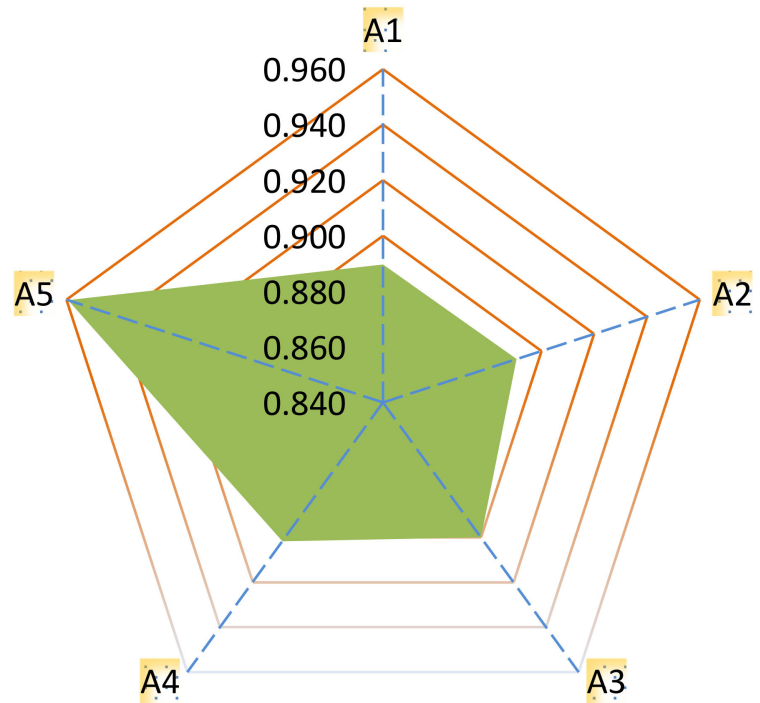

- Weight Remains Constant

Figure 3. Degree of the closeness coefficient (CC) of possible pathways.

The findings of the results may facilitate the beneficiaries and concerned stakeholders to grasp complete scenario of the barriers confronted in adoption of SSCIs. The proposed framework would be a helping tool to enhance the organizational performance of the FPIs and sustain the competitive advantages in line towards business excellence.

\subsection{Validating Results by Applying Sensitivity Analysis}

The results validation can be proved by applying the sensitivity analysis, and it can be performed to confirm the authenticity of the results of this research [101-103]. The experts provided the inputs in qualitative form in this study; therefore, they may have chances of inaccuracy in giving different weights to set of alternatives. Therefore, it is very important to check the robustness of the results by applying the sensitivity analysis. The researchers performed the sensitivity analysis in three scenarios for confirming the variations in the results. In the first scenario, the weight increased by $10 \%$ of 'possible pathways one element and decreased other elements' weight, accordingly. In the second scenario, the weight decreased by $10 \%$ of 'possible pathways one element and increased other elements' weight, accordingly. In the third scenario, the weight of possible pathways remained the same, and it remained constant correspondingly. It was noticed that there was no major fluctuation in the weight values of possible pathways, as they were depicting a stable 
solution. These results are shown in Table 13. As this study applied the fuzzy triangular numbers (FTNs) for evaluation; hence, the options of inaccuracy or vagueness are lower. Despite this, we need to do this analysis to check the fluctuations among our figures, and these are highlighted in Figure 4 as well as given in Table 13. These results indicate stability when the weight of different alternatives is changed. The fluctuations among the results of possible pathways values is minor, which indicates the higher level of stability in the proposed framework. The authenticity of sensitivity analysis applied is in accordance with the previous literature on similar types of research in different sectors [35].

Table 13. Sensitivity Analysis of Possible Pathways by Changing the Weights.

\begin{tabular}{ccccc}
\hline & Possible Pathways & Weight Remained Unchanged & Weight Increased by 10\% & Weight Decreased by 10\% \\
\hline $\mathrm{A}_{1}$ & Lean management & 0.890 & 0.979 & 0.792 \\
$\mathrm{~A}_{2}$ & Appropriate infrastructure & 0.891 & 0.980 & 0.793 \\
$\mathrm{~A}_{3}$ & $\begin{array}{c}\text { Sustainable technology and } \\
\text { techniques }\end{array}$ & 0.900 & 0.990 & 0.801 \\
$\mathrm{~A}_{4}$ & $\begin{array}{c}\text { Cleaner production and } \\
\text { recyclability }\end{array}$ & 0.902 & 0.992 & 0.803 \\
$\mathrm{~A}_{5}$ & Procurement management & 0.959 & 0.998 & 0.854 \\
\hline
\end{tabular}

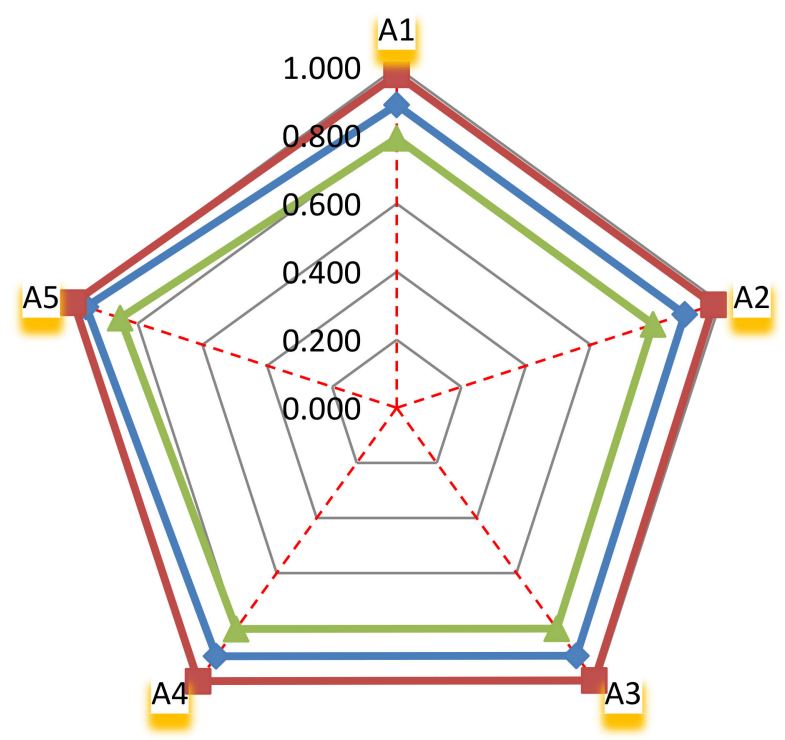

- Weight Remains Constant

-Weight Increased by $10 \%$

- Weight Decreased by $10 \%$

Figure 4. Sensitivity analysis results by changing weightage of CC values.

\subsection{Comparison with Existing Literature}

It is essential to evaluate the barriers to implement SSCI in the food processing industries in order to sustain across the globe [104]. The assessment of barriers to SSCI may vary from one geography to another geography due to the presence of several constraints [105]. In this study, the fuzzy AHP-TOPSIS method presented the most important barriers related to Pakistani FPIs. The problems faced in maintaining sustainable suppliers (SO1) has been identified as the most important sub-barrier. The small agro based industries find it difficult to maintain sustainable suppliers as the interest of supplier is different in the entire supply chain. Hashim et al. [6] developed a model for sustainable strategic supplier selection and suggested that maintaining the sustainable suppliers is one of the most important barriers to implement SSCIs in Pakistani textile industries through multiobjective optimization through genetic algorithms. Lack of buyer-supplier relationships may create more challenges during the procurement process. These challenges enhance the problems of managing the price and quality of the products [31]. Secondly, the complexity in monitoring suppliers' eco-practices (SO2) barrier ranks as a highly prioritized factor. Ageron et al. [63] stated that, due to conservative managerial styles, it's difficult mitigate 
the eco-friendly practices of suppliers, which may affect the organizational greener supply chain environment. Due to lack of compliance and implementation of ISO 14,001 standards, firms face challenges to keep buyer-supplier partnerships in the entire supply chain of FPIs. The lack of getting a competitive advantage to keep the competition in market (SCI1) barrier ranks the third position in this research. Rasool et al. [22] discussed this barrier, in the context of the textile supply chain, and considered it as the most potential barriers. The results reveal that it is very difficult to adopt sustainability initiatives in a shorter time span, therefore, an action plan is needed, in terms of possible pathways, to implement supply chain practices in a timely way. The procurement management is crucial while addressing the sustainability related barriers. Therefore, FPIs in Pakistan are in dire need of sustainable supply chain strategies that could help them in managing these barriers, which are analyzed and interpreted, scientifically, through this research.

\section{Implications Based on Research Findings}

\subsection{Managerial Implications}

It is a complicated task for management of FPIs to adopt SSCIs abruptly without eradication of potential barriers. Due to this reason, managers have to assess higher priority level barriers among others for SSCI adoption. In this study, firstly, sustainable outsourcing dimension is found out to be highly prioritized barrier, therefore, the management should concentrate more on outsourcing related challenges. Additionally, they have to develop strong buyer-supplier relationships based on eco-friendly practices. Nowadays, the producers are reluctant to educate and train the personnel of suppliers for adopting sustainable concepts [106]. Managers need to minimize the trust deficit among buyers and suppliers. Secondly, the alternative possible pathways $A_{5}$ is highly prioritized during SSCIs adoption, and firms need to pay more attention to the procurement management. The results reveal that it is very difficult to adopt sustainability initiatives in a shorter time span. It means that the identification of barriers is a helping tool for the management of firms to redesign business continuity long-term programs and also to formulate eco-friendly, socially responsible, and economically viable strategies. The outcome of this research would be helpful for targeting those companies, which are not well aware about the sustainable concepts, cleaner production, and recyclability. Finally, the findings of this research may facilitate operation and production management in strengthening SSCM initiatives in the SCs of FPIs.

\subsection{Theoretical Implications}

This research study explored the key barriers encountered in adopting the SSCIs and also prioritized the salient possible pathways as roadmap in the emerging economies context. This study bridges the gap between academia and industry by strengthening the domestic, as well as international, beneficiaries to adopt SSCIs. It also contributed in the literature of fuzzy set theory by introducing the hybrid multi-criteria decision making methods based on the sensitivity analysis [107]. Nowadays, the FPIs are under pressure from the domestic and global supply chain stakeholders to apply SSCIs related practices in order to minimize the adverse impact of socio-economic and environmental factors. Furthermore, the findings of this study can be compared with other methodologies, such as data mining techniques, multi-objective optimization techniques, and heuristic methods, etc.

\subsection{Policy Implications}

The Government should lay emphasis on the implementation of SSCIs by providing the monetary incentives to the industries, dealings in import and export of the products. These practices would lead towards more commitment and dedication from the strategic management, otherwise the lack of Government support will be treated as the most critical challenge for the firms. The policy makers and expatriates may take initiatives towards greener practices and compliance of well-known standards such as ISO:14001:2004 
(Environment Management System), ISO:9001:2015 (Quality Management System), ISO:20400 (Sustainable Procurement), and ISO:26000:2010 (Guidance on Social Responsibility) standards. The Government should launch awareness campaigns to promote these standards through different platforms. The adequate budget should be allocated for the R\&D, and its strict compliance must be monitored. Furthermore, the Government needs to launch awareness campaigns, regarding the user friendly products, and suggest the roadmap of how they are helpful to them. A well-established training and development wing should be operated to provide trainings to the workers, frequently, about new tools in the sustainable supply chain. Finally, the results suggest that sustainability can be achieved by developing the appropriate measures of the procurement cycle and further vendor evaluation during a purchasing process.

\section{Concluding Remarks}

The SSCIs implementation in FPIs is crucial and needs support from top level management to bottom-line workers in the workforce. The identification and prioritization of barriers is a thought-provoking process due to the uncertain supply chain environment. The success ratio of SSCIs adoption in the supply chain of FPIs is comparatively lower due to the certain barriers and limited solution options. Therefore, this study aims to propose and prioritize the possible pathways in line towards improving supply chain performance. A hybrid fuzzy AHP-TOPSIS framework was developed, and the overall work was explained in three main phases, as previously discussed. The first phase discussed the extract of literature review and inputs of experts (professor, production manager, and supply chain manager) for scoring the sustainability related-criterion, sub-criterion, and alternatives. The second phase determined the weight of criteria and sub-criteria using fuzzy AHP method. The third phase prioritized and ranked the alternative possible pathways, applying fuzzy TOPSIS along implications of the research for the concerned stakeholders. The results suggest that a lack of sustainable outsourcing barrier category taken as the leading category of barriers, due to higher weightage value. Finally, the results deduced depict that $A_{5}$ has the highest $C C_{i}$, therefore, the prioritization among possible pathways can be observed and sorted as: A5 $>$ A4 $>$ A3 $>$ A2 $>$ A1. The outcome of this research would be helpful for targeting those companies which are not well aware about the sustainable concepts, cleaner production, and recyclability. Furthermore, the policy maker needs to develop policies, regarding the user friendly products, and guide the beneficiaries on how they are helpful to them. A well-established training and development wing should be operated to provide trainings to the workers of FPIs about new practices in achieving sustainable business goals.

This research also has some limitations such as: first, this study considered only five possible pathways, based upon forty two sub-criterion and seven main criterion, and second, experts were selected only from Pakistani FPIs and academia. Therefore, the results cannot be generalized for FPIs located in surrounding countries. Moreover, the present study is not using any statistical analysis approach to check incremental changes among the barriers. In the future, the authors may include more criteria and sub-criteria, which have not been treated right now. This study is conducted in the agro-based processing industries, considering the Pakistani perspective; however, the proposed framework may also be applied to other developing countries to make comparisons and obtain more widespread findings. In the future studies, the fuzzy tools can be integrated with structural equation modeling using smart PLS software. The barriers of different supply chain practices such as circular economy, procurement strategies, resilient transportation, reverse logistics, supply chain agility, supply chain digitalization, and industry 4.0 can also be assessed by taking this study framework. Similar types of other multi-criteria methods, such as Decision Making Trial and Evaluation Laboratory (DEMATEL), Analytic Network Process (ANP), fuzzy PROMETHEE, fuzzy ELECTRE, and fuzzy VIKOR can also be used to confirm the accuracy and robustness of the proposed results. Furthermore, the current study, based on fuzzy set theory, can be extended by adopting advanced methodologies, such as data 
mining techniques (classification, clustering, and regression), game theoretic methods (mini-max theorem), optimization techniques (Monte-Carlo simulation), and heuristic methods (genetic algorithms), etc.

Author Contributions: Conceptualization, M.N., T.A. and S.W.; M.M.; M.N. and M.H.; methodology, M.N.; validation of data, M.N., M.H. and S.A.B.; writing-review and editing, M.Z.R. and M.H.; proof reading S.A.B. and M.Z.R. All authors have read and agreed to the published version of the manuscript.

Funding: This research received no external funding.

Institutional Review Board Statement: Not applicable.

Informed Consent Statement: Not applicable.

Data Availability Statement: Please contact the corresponding author via email for the data.

Acknowledgments: The authors would like to thank the Editors and the anonymous referees as well as experts from food processing industries and academia for providing their very valuable suggestions in improving the quality of the present research work.

Conflicts of Interest: The authors declare no conflict of interest.

\section{Appendix A}

Table A1. The pairwise comparison matrix of the major criterion, formulated with Saaty's nine point scale.

\begin{tabular}{cccccccc}
\hline & SO & SPD & SCI & SBSR & SMOC & SKS & ST \\
\hline SO & 1.00 & 2.00 & 3.00 & 2.00 & 3.00 & 2.00 & 3.00 \\
SPD & 0.50 & 1.00 & 3.00 & 2.00 & 3.00 & 2.00 & 2.00 \\
SCI & 0.33 & 0.33 & 1.00 & 2.00 & 2.00 & 2.00 & 2.00 \\
SBSR & 0.50 & 0.50 & 0.50 & 1.00 & 3.00 & 2.00 & 3.00 \\
SMOC & 0.33 & 0.33 & 0.50 & 0.33 & 1.00 & 2.00 & 2.00 \\
SKS & 0.50 & 0.50 & 0.50 & 0.50 & 0.50 & 1.00 & 2.00 \\
ST & 0.33 & 0.50 & 0.50 & 0.33 & 0.50 & 0.50 & 1.00 \\
\hline
\end{tabular}

Table A2. Pairwise comparison matrix of the sustainable outsourcing (SO) barriers.

\begin{tabular}{lllllll}
\hline & $\mathbf{S O}_{\mathbf{1}}$ & $\mathbf{S O}_{\mathbf{2}}$ & $\mathbf{S O}_{\mathbf{3}}$ & $\mathbf{S O}_{\mathbf{4}}$ & $\mathbf{S O}_{\mathbf{5}}$ & $\mathbf{S O}_{\mathbf{6}}$ \\
\hline $\mathrm{SO}_{1}$ & 1.00 & 2.00 & 3.00 & 2.00 & 3.00 & 7.00 \\
$\mathrm{SO}_{2}$ & 0.50 & 1.00 & 3.00 & 2.00 & 3.00 & 3.00 \\
$\mathrm{SO}_{3}$ & 0.33 & 0.33 & 1.00 & 2.00 & 2.00 & 2.00 \\
$\mathrm{SO}_{4}$ & 0.50 & 0.50 & 0.50 & 1.00 & 2.00 & 3.00 \\
$\mathrm{SO}_{5}$ & 0.33 & 0.33 & 0.50 & 0.50 & 1.00 & 2.00 \\
$\mathrm{SO}_{6}$ & 0.14 & 0.33 & 0.50 & 0.33 & 0.50 & 1.00 \\
\hline
\end{tabular}

Table A3. Pairwise comparison matrix of the sustainable production and distribution (SPD) barriers.

\begin{tabular}{lccccccc}
\hline & SPD $_{\mathbf{1}}$ & SPD $_{\mathbf{2}}$ & SPD $_{\mathbf{3}}$ & SPD $_{\mathbf{4}}$ & SPD $_{\mathbf{5}}$ & SPD $_{\mathbf{6}}$ & SPD $_{\mathbf{7}}$ \\
\hline $\mathrm{SPD}_{1}$ & 1.00 & 2.00 & 3.00 & 3.00 & 2.00 & 3.00 & 2.00 \\
$\mathrm{SPD}_{2}$ & 0.50 & 1.00 & 2.00 & 2.00 & 4.00 & 3.00 & 2.00 \\
$\mathrm{SPD}_{3}$ & 0.33 & 0.50 & 1.00 & 2.00 & 3.00 & 2.00 & 3.00 \\
$\mathrm{SPD}_{4}$ & 0.33 & 0.50 & 0.50 & 1.00 & 2.00 & 3.00 & 3.00 \\
$\mathrm{SPD}_{5}$ & 0.50 & 0.25 & 0.33 & 0.50 & 1.00 & 3.00 & 2.00 \\
$\mathrm{SPD}_{6}$ & 0.33 & 0.33 & 0.50 & 0.33 & 0.33 & 1.00 & 2.00 \\
$\mathrm{SPD}_{7}$ & 0.50 & 0.50 & 0.33 & 0.33 & 0.50 & 0.50 & 1.00 \\
\hline
\end{tabular}


Table A4. Pairwise comparison matrix of the sustainable competitiveness and innovation (SCI) barriers.

\begin{tabular}{lcccc}
\hline & $\mathbf{S C I}_{\mathbf{1}}$ & $\mathbf{S C I}_{\mathbf{2}}$ & $\mathbf{S C I}_{\mathbf{3}}$ & $\mathbf{S C I}_{\mathbf{4}}$ \\
\hline $\mathrm{SCI}_{1}$ & 1.00 & 3.00 & 4.00 & 2.00 \\
$\mathrm{SCI}_{2}$ & 0.33 & 1.00 & 3.00 & 2.00 \\
$\mathrm{SCI}_{3}$ & 0.25 & 0.33 & 1.00 & 2.00 \\
$\mathrm{SCI}_{4}$ & 0.50 & 0.50 & 0.50 & 1.00 \\
\hline
\end{tabular}

Table A5. Pairwise comparison matrix of the sustainable buyer-supplier relationship (SBSR) barriers.

\begin{tabular}{lccccccc}
\hline & SBSR $_{\mathbf{1}}$ & SBSR $_{\mathbf{2}}$ & SBSR $_{\mathbf{3}}$ & SBSR $_{\mathbf{4}}$ & SBSR $_{\mathbf{5}}$ & SBSR $_{\mathbf{6}}$ & SBSR $_{\mathbf{7}}$ \\
\hline SBSR $_{1}$ & 1.00 & 2.00 & 2.00 & 3.00 & 2.00 & 3.00 & 2.00 \\
SBSR $_{2}$ & 0.50 & 1.00 & 3.00 & 5.00 & 3.00 & 4.00 & 2.00 \\
SBSR $_{3}$ & 0.50 & 0.33 & 1.00 & 2.00 & 3.00 & 5.00 & 2.00 \\
SBSR $_{4}$ & 0.33 & 0.20 & 0.50 & 1.00 & 2.00 & 3.00 & 3.00 \\
SBSR $_{5}$ & 0.50 & 0.33 & 0.33 & 0.50 & 1.00 & 4.00 & 2.00 \\
SBSR $_{6}$ & 0.33 & 0.33 & 0.20 & 0.33 & 0.25 & 1.00 & 2.00 \\
SBSR $_{7}$ & 0.20 & 0.50 & 0.50 & 0.33 & 0.50 & 0.50 & 1.00 \\
\hline
\end{tabular}

Table A6. Pairwise comparison matrix of the sustainable marketing and organizational culture (SMOC) barriers.

\begin{tabular}{lccccccc}
\hline & SMOC $_{\mathbf{1}}$ & SMOC $_{\mathbf{2}}$ & SMOC $_{\mathbf{3}}$ & SMOC $_{4}$ & SMOC $_{5}$ & SMOC $_{\mathbf{6}}$ & SMOC $_{\mathbf{7}}$ \\
\hline $\mathrm{SMOC}_{1}$ & 1.00 & 3.00 & 2.00 & 2.00 & 3.00 & 2.00 & 2.00 \\
$\mathrm{SMOC}_{2}$ & 0.33 & 1.00 & 0.30 & 1.00 & 3.00 & 3.00 & 2.00 \\
$\mathrm{SMOC}_{3}$ & 0.50 & 3.00 & 1.00 & 0.33 & 3.00 & 2.00 & 2.00 \\
$\mathrm{SMOC}_{4}$ & 0.50 & 1.00 & 3.00 & 1.00 & 5.00 & 3.00 & 3.00 \\
$\mathrm{SMOC}_{5}$ & 0.33 & 0.33 & 0.33 & 0.20 & 1.00 & 2.00 & 2.00 \\
$\mathrm{SMOC}_{6}$ & 0.50 & 0.33 & 0.50 & 0.33 & 0.50 & 1.00 & 2.00 \\
$\mathrm{SMOC}_{7}$ & 0.50 & 0.50 & 0.50 & 0.33 & 0.50 & 0.50 & 1.00 \\
\hline
\end{tabular}

Table A7. Pairwise comparison matrix of the sustainable knowledge sharing (SKS) barriers.

\begin{tabular}{cccccc}
\hline & SKS $_{\mathbf{1}}$ & SKS $_{\mathbf{2}}$ & SKS $_{\mathbf{3}}$ & SKS $_{\mathbf{4}}$ & SKS $_{\mathbf{5}}$ \\
\hline $\mathrm{SKS}_{1}$ & 1.00 & 0.33 & 2.00 & 3.00 & 2.00 \\
$\mathrm{SKS}_{2}$ & 3.00 & 1.00 & 3.00 & 2.00 & 5.00 \\
$\mathrm{SKS}_{3}$ & 0.20 & 0.33 & 1.00 & 2.00 & 2.00 \\
$\mathrm{SKS}_{4}$ & 0.33 & 0.50 & 0.50 & 1.00 & 2.00 \\
$\mathrm{SKS}_{5}$ & 0.50 & 0.20 & 0.50 & 0.50 & 1.00 \\
\hline
\end{tabular}

Table A8. Pairwise comparison matrix of the sustainable technology (ST) barriers.

\begin{tabular}{lllllll}
\hline & $\mathbf{S T}_{\mathbf{1}}$ & $\mathbf{S T}_{\mathbf{2}}$ & $\mathbf{S T}_{\mathbf{3}}$ & $\mathbf{S T}_{\mathbf{4}}$ & $\mathbf{S T}_{\mathbf{5}}$ & $\mathbf{S T}_{\mathbf{6}}$ \\
\hline $\mathrm{ST}_{1}$ & 1.00 & 3.00 & 9.00 & 1.00 & 5.00 & 3.00 \\
$\mathrm{ST}_{2}$ & 0.33 & 1.00 & 7.00 & 0.20 & 5.00 & 4.00 \\
$\mathrm{ST}_{3}$ & 0.11 & 0.14 & 1.00 & 0.11 & 0.20 & 3.00 \\
$\mathrm{ST}_{4}$ & 1.00 & 5.00 & 9.00 & 1.00 & 7.00 & 5.00 \\
$\mathrm{ST}_{5}$ & 0.20 & 0.20 & 5.00 & 0.14 & 1.00 & 2.00 \\
$\mathrm{ST}_{6}$ & 0.33 & 0.25 & 0.33 & 0.20 & 0.50 & 1.00 \\
\hline
\end{tabular}




\section{References}

1. Li, S.; Lin, B. Accessing information sharing and information quality in supply chain management. Decis. Support Syst. 2006, 42, 1641-1656. [CrossRef]

2. Nazam, M.; Hashim, M.; Randhawa, M.A.; Maqbool, A. Modeling the Barriers of Sustainable Supply Chain Practices: A Pakistani Perspective. In Proceedings of the International Conference on Management Science and Engineering Management, Ontario, ON, Canada, 5-8 August 2019; pp. 348-364.

3. Mumtaz, U.; Ali, Y.; Petrillo, A.; De Felice, F. Identifying the critical factors of green supply chain management: Environmental benefits in Pakistan. Sci. Total Environ. 2018, 640-641, 144-152. [CrossRef]

4. Siddiqui, F.; Haleem, A.; Sharma, C. The Impact of Supply Chain Management Practices in Total Quality Management Practices and Flexible System Practices Context: An Empirical Study in Oil and Gas Industry. Glob. J. Flex. Syst. Manag. 2012, 13, 11-23. [CrossRef]

5. Mau, M. Supply chain management in agriculture-including economics aspects like responsibility and transparency. In Proceedings of the Xth EAAE Congress 'Exploring Diversity in the European Agri-Food System', Zaragoza, Spain, 28-31 August 2002.

6. Hashim, M.; Nazam, M.; Yao, L.; Baig, S.A.; Abrar, M.; Zia-Ur-Rehman, M. Application of multi-objective optimization based on genetic algorithm for sustainable strategic supplier selection under fuzzy environment. J. Ind. Eng. Manag. 2017, 10, 188. [CrossRef]

7. Klassen, R.D.; Vereecke, A. Social issues in supply chains: Capabilities link responsibility, risk (opportunity), and performance. Int. J. Prod. Econ. 2012, 140, 103-115. [CrossRef]

8. Nazam, M.; Xu, J.; Tao, Z.; Ahmad, J.; Hashim, M. A fuzzy AHP-TOPSIS framework for the risk assessment of green supply chain implementation in the textile industry. Int. J. Supply Oper. Manag. 2015, 2, 548-568.

9. Liu, J.; Sarkar, S.; Kumar, S.; Jin, Z. An analysis of stock market impact from supply chain disruptions in Japan. Int. J. Prod. Perform. Manag. 2018, 67, 192-206. [CrossRef]

10. Mudgal, R.K.; Shankar, R.; Talib, P.; Raj, T. Modelling the barriers of green supply chain practices: An Indian perspective. Int. J. Logist. Syst. Manag. 2010, 7, 81. [CrossRef]

11. Carter, C.R.; Dresner, M. Purchasing's Role in Environmental Management: Cross-Functional Development of Grounded Theory. J. Supply Chain Manag. 2001, 37, 12-27. [CrossRef]

12. Carter, C.R.; Rogers, D.S. A framework of sustainable supply chain management: Moving toward new theory. Int. J. Phys. Distrib. Logist. Manag. 2008, 38, 360-387. [CrossRef]

13. Wu, K.-J.; Tseng, M.-L.; Vy, T. Evaluation the drivers of green supply chain management practices in uncertainty. Procedia Soc. Behav. Sci. 2011, 25, 384-397. [CrossRef]

14. Zhu, Q.; Geng, Y.; Fujita, T.; Hashimoto, S. Green supply chain management in leading manufacturers. Manag. Res. Rev. 2010, 33, 380-392. [CrossRef]

15. Dan, B.; Liu, F. Study on green supply chain and its architecture. J. Chin. Soc. Mech. Eng. 2000, 11, 1232-1234.

16. Darnall, N.; Jolley, G.J.; Handfield, R. Environmental management systems and green supply chain management: Complements for sustainability? Bus. Strat. Environ. 2007, 17, 30-45. [CrossRef]

17. Shalke, P.N.; Paydar, M.M.; Hajiaghaei-Keshteli, M. Sustainable supplier selection and order allocation through quantity discounts. Int. J. Manag. Sci. Eng. Manag. 2018, 13, 20-32. [CrossRef]

18. Thuong, N.T.H.; Zhang, R.; Li, Z.; Hong, P.T.D. Multi-criteria evaluation of financial statement quality based on hesitant fuzzy judgments with assessing attitude. Int. J. Manag. Sci. Eng. Manag. 2018, 13, 1-11. [CrossRef]

19. Singh, M.D.; Kant, R. Knowledge management barriers: An interpretive structural modeling approach. Int. J. Manag. Sci. Eng. Manag. 2008, 3, 141-150. [CrossRef]

20. Diabat, A.; Govindan, K. An analysis of the drivers affecting the implementation of green supply chain management. Resour. Conserv. Recycl. 2011, 55, 659-667. [CrossRef]

21. Zhu, Q.; Sarkis, J.; Lai, K.-H. Confirmation of a measurement model for green supply chain management practices implementation. Int. J. Prod. Econ. 2008, 111, 261-273. [CrossRef]

22. Rasool, Y.; Ahmad, W.; Nazam, M. Empirical study on implementation of sustainable supply chain management: A case of textile sector. Int. J. Sustain. Manag. Inf. Technol. 2016, 2, 21-27.

23. Christopher, M.; Holweg, M. "Supply Chain 2.0": Managing supply chains in the era of turbulence. Int. J. Phys. Distrib. Logist. Manag. 2011, 41, 63-82. [CrossRef]

24. Saaty, T.L. The Analytic Hierarchy Process; McGraw Hill International: New York, NY, USA, 1980.

25. Talluri, S.; Kull, T.J.; Yildiz, H.; Yoon, J. Assessing the Efficiency of Risk Mitigation Strategies in Supply Chains. J. Bus. Logist. 2013, 34, 253-269. [CrossRef]

26. Sarkis, J.; Helms, M.M.; Hervani, A.A. Reverse logistics and social sustainability. Corp. Soc. Responsib. Environ. Manag. 2010, 17, 337-354. [CrossRef]

27. Ferretti, I.; Zanoni, S.; Zavanella, L.; Diana, A. Greening the aluminium supply chain. Int. J. Prod. Econ. 2007, 108, 236-245. [CrossRef]

28. Walton, S.V.; Handfield, R.B.; Melnyk, S.A. The Green Supply Chain: Integrating Suppliers into Environmental Management Processes. Int. J. Purch. Mater. Manag. 1998, 34, 2-11. [CrossRef] 
29. Chen, C.-C.; Shih, H.-S.; Shyur, H.-J.; Wu, K.-S. A business strategy selection of green supply chain management via an analytic network process. Comput. Math. Appl. 2012, 64, 2544-2557. [CrossRef]

30. Zhu, Q.; Sarkis, J.; Lai, K.-H. Examining the effects of green supply chain management practices and their mediations on performance improvements. Int. J. Prod. Res. 2012, 50, 1377-1394. [CrossRef]

31. Mangla, S.K.; Govindan, K.; Luthra, S. Prioritizing the barriers to achieve sustainable consumption and production trends in supply chains using fuzzy Analytical Hierarchy Process. J. Clean. Prod. 2017, 151, 509-525. [CrossRef]

32. Rao, P.; Holt, D. Do green supply chains lead to competitiveness and economic performance? Int. J. Oper. Prod. Manag. 2005, 25, 898-916. [CrossRef]

33. Beamon, B.M. Designing the green supply chain. Logist. Inf. Manag. 1999, 12, 332-342. [CrossRef]

34. Rostamzadeh, R.; Ghorabaee, M.K.; Govindan, K.; Esmaeili, A.; Nobar, H.B.K. Evaluation of sustainable supply chain risk management using an integrated fuzzy TOPSIS- CRITIC approach. J. Clean. Prod. 2018, 175, 651-669. [CrossRef]

35. Junaid, M.; Xue, Y.; Syed, M.W.; Zu Li, J.; Ziaullah, M. A Neutrosophic AHP and TOPSIS Framework for Supply Chain Risk Assessment in Automotive Industry of Pakistan. Sustainability 2019, 12, 154. [CrossRef]

36. Abbasi, M. Sustainable practices in Pakistani manufacturing supply chains: Motives, sharing mechanism and performance outcome. J. Qual. Technol. Manag. 2012, 8, 51-74.

37. Sloan, K.; Klingenberg, B.; Rider, C. Towards Sustainability: Examining the Drivers and Change Process within SMEs. J. Manag. Sustain. 2013, 3, 19. [CrossRef]

38. Calleja, I.; Delgado, L.; Eder, P.; Kroll, A.; Lindblom, J.; Wunnik, C.; Wolf, O. Promoting Environmental Technologies: Sectoral Analysis, Barriers and Measures; European Commission: Brussels, Belgium, 2004.

39. Ninlawan, C.; Seksan, P.; Tossapol, K.; Pilada, W. The implementation of green supply chain management practices in electronics industry. In Proceedings of the World Congress on Engineering, London, UK, 4-6 July 2012; pp. 1563-1568.

40. Hervani, A.A.; Helms, M.M.; Sarkis, J. Performance measurement for green supply chain management. Benchmarking Int. J. 2005, 12, 330-353. [CrossRef]

41. Björklund, M.; Martinsen, U.; Abrahamsson, M. Performance measurements in the greening of supply chains. Supply Chain Manag. Int. J. 2012, 17, 29-39. [CrossRef]

42. Wolf, C.; Seuring, S. Environmental impacts as buying criteria for third party logistical services. Int. J. Phys. Distrib. Logist. Manag. 2010, 40, 84-102. [CrossRef]

43. Abdulrahman, M.D.; Gunasekaran, A.; Subramanian, N. Critical barriers in implementing reverse logistics in the Chinese manufacturing sectors. Int. J. Prod. Econ. 2014, 147, 460-471. [CrossRef]

44. Long, T.B.; Blok, V.; Coninx, I. Barriers to the adoption and diffusion of technological innovations for climate-smart agriculture in Europe: Evidence from the Netherlands, France, Switzerland and Italy. J. Clean. Prod. 2016, 112, 9-21. [CrossRef]

45. Winkler, H. Closed-loop production systems-A sustainable supply chain approach. CIRP J. Manuf. Sci. Technol. 2011, 4, 243-246. [CrossRef]

46. De Brito, M.P.; Carbone, V.; Blanquart, C.M. Towards a sustainable fashion retail supply chain in Europe: Organisation and performance. Int. J. Prod. Econ. 2008, 114, 534-553. [CrossRef]

47. Dubey, R.; Gunasekaran, A. The sustainable humanitarian supply chain design: Agility, adaptability and alignment. Int. J. Logist. Res. Appl. 2016, 19, 62-82. [CrossRef]

48. Wang, X.; Durugbo, C. Analysing network uncertainty for industrial product-service delivery: A hybrid fuzzy approach. Expert Syst. Appl. 2013, 40, 4621-4636. [CrossRef]

49. Lehtoranta, S.; Nissinen, A.; Mattila, T.; Melanen, M. Industrial symbiosis and the policy instruments of sustainable consumption and production. J. Clean. Prod. 2011, 19, 1865-1875. [CrossRef]

50. Sabri, E.H.; Shaikh, S.N. Lean and Agile Value Chain Management: A Guide to the Next Level of Improvement; J Ross Publishing: Fort Lauderdale, FL, USA, 2010.

51. Diabat, A.; Kannan, D.; Mathiyazhagan, K. Analysis of enablers for implementation of sustainable supply chain management-A textile case. J. Clean. Prod. 2014, 83, 391-403. [CrossRef]

52. Harik, R.; EL Hachem, W.; Medini, K.; Bernard, A. Towards a holistic sustainability index for measuring sustainability of manufacturing companies. Int. J. Prod. Res. 2014, 53, 4117-4139. [CrossRef]

53. Govindan, K.; Khodaverdi, R.; Jafarian, A. A fuzzy multi criteria approach for measuring sustainability performance of a supplier based on triple bottom line approach. J. Clean. Prod. 2013, 47, 345-354. [CrossRef]

54. Revell, A.; Rutherfoord, R. UK environmental policy and the small firm: Broadening the focus. Bus. Strat. Environ. 2003, 12, 26-35. [CrossRef]

55. Lee, S. Drivers for the participation of small and medium-sized suppliers in green supply chain initiatives. Supply Chain Manag. Int. J. 2008, 13, 185-198. [CrossRef]

56. Eftekhary, M.; Safari, S.; Shojaee, M.; Assarian, M.; Karimi, I. Identifying customers' needs on electronic services of bank using fuzzy QFD approach. Aust. J. Basic Appl. Sci. 2012, 6, 287-296.

57. Banaeian, N.; Mobli, H.; Fahimnia, B.; Nielsen, I.E.; Omid, M. Green supplier selection using fuzzy group decision making methods: A case study from the agri-food industry. Comput. Oper. Res. 2018, 89, 337-347. [CrossRef]

58. Sharma, A.; Iyer, G.R.; Mehrotra, A.; Krishnan, R. Sustainability and business-to-business marketing: A framework and implications. Ind. Mark. Manag. 2010, 39, 330-341. [CrossRef] 
59. Tseng, M.; Lim, M.K.; Wong, W.P. Sustainable supply chain management. Ind. Manag. Data Syst. 2015, 115, 436-461. [CrossRef]

60. Tanner, C.; Kast, S.W. Promoting sustainable consumption: Determinants of green purchases by Swiss consumers. Psychol. Mark. 2003, 20, 883-902. [CrossRef]

61. Veleva, V.; Ellenbecker, M. Indicators of sustainable production: Framework and methodology. J. Clean. Prod. 2001, 9, 519-549. [CrossRef]

62. Tseng, M.-L. A causal and effect decision making model of service quality expectation using grey-fuzzy DEMATEL approach. Expert Syst. Appl. 2009, 36, 7738-7748. [CrossRef]

63. Ageron, B.; Gunasekaran, A.; Spalanzani, A. Sustainable supply management: An empirical study. Int. J. Prod. Econ. 2012, 140, 168-182. [CrossRef]

64. Chen, I.J.; Paulraj, A. Understanding supply chain management: Critical research and a theoretical framework. Int. J. Prod. Res. 2004, 42, 131-163. [CrossRef]

65. Lin, C.-Y.; Ho, Y.-H. An empirical study on logistics service providers' intention to adopt green innovations. J. Technol. Manag. Innov. 2008, 3, 17-26.

66. Akenji, L.; Bengtsson, M. Making Sustainable Consumption and Production the Core of Sustainable Development Goals. Sustainability 2014, 6, 513-529. [CrossRef]

67. Almeida, C.; Bonilla, B.; Giannetti, F.; Huisingh, D. Cleaner Production Initiatives and Challenges for a Sustainable World: An Introduction to This Special Volume; Elsevier: Amsterdam, The Netherlands, 2013.

68. Christopher, M.; Mena, C.; Khan, O.; Yurt, O. Approaches to managing global sourcing risk. Supply Chain Manag. Int. J. 2011, 16, 67-81. [CrossRef]

69. Longoni, A.; Golini, R.; Cagliano, R. The role of New Forms of Work Organization in developing sustainability strategies in operations. Int. J. Prod. Econ. 2014, 147, 147-160. [CrossRef]

70. Bouzon, M.; Govindan, K.; Rodriguez, C.M.; Campos, L.M.S. Identification and analysis of reverse logistics barriers using fuzzy Delphi method and AHP. Resour. Conserv. Recycl. 2016, 108, 182-197. [CrossRef]

71. Patil, S.; Kant, R. A fuzzy AHP-TOPSIS framework for ranking the solutions of Knowledge Management adoption in Supply Chain to overcome its barriers. Expert Syst. Appl. 2014, 41, 679-693. [CrossRef]

72. Hutzschenreuter, T.; Horstkotte, J. Knowledge transfer to partners: A firm level perspective. J. Knowl. Manag. 2010, 14, 428-448. [CrossRef]

73. Li, X.; Hu, J. Business Impact Analysis Based on Supply Chain's Knowledge Sharing ability. Procedia Environ. Sci. 2012, 12, 1302-1307. [CrossRef]

74. Walker, H.; Di Sisto, L.; McBain, D. Drivers and barriers to environmental supply chain management practices: Lessons from the public and private sectors. J. Purch. Supply Manag. 2008, 14, 69-85. [CrossRef]

75. Andiç, E.; Yurt, Ö.; Baltacığlu, T. Green supply chains: Efforts and potential applications for the Turkish market. Resour. Conserv. Recycl. 2012, 58, 50-68. [CrossRef]

76. Hillary, R. Environmental management systems and the smaller enterprise. J. Clean. Prod. 2004, 12, 561-569. [CrossRef]

77. Kim, D.; Cavusgil, S.T.; Calantone, R.J. Information System Innovations and Supply Chain Management: Channel Relationships and Firm Performance. J. Acad. Mark. Sci. 2006, 34, 40-54. [CrossRef]

78. Cecere, G.; Mazzanti, M. Green jobs and eco-innovations in European SMEs. Resour. Energy Econ. 2017, 49, 86-98. [CrossRef]

79. Theyel, G. Management practices for environmental innovation and performance. Int. J. Oper. Prod. Manag. 2000, 20, 249-266. [CrossRef]

80. Gunasekaran, A.; Ngai, E.W. Information systems in supply chain integration and management. Eur. J. Oper. Res. 2004, 159, 269-295. [CrossRef]

81. Joshi, K.; Sarker, S.; Sarker, S. Knowledge transfer within information systems development teams: Examining the role of knowledge source attributes. Decis. Support Syst. 2007, 43, 322-335. [CrossRef]

82. Kasper, H.; Mühlbacher, J.; Müller, B. Intra-organizational knowledge sharing in MNCs depending on the degree of decentralization and communities of practice. J. Glob. Bus. Technol. 2008, 4, 1.

83. Haq, A.N.; Kannan, G. Design of an integrated supplier selection and multi-echelon distribution inventory model in a built-toorder supply chain environment. Int. J. Prod. Res. 2006, 44, 1963-1985. [CrossRef]

84. Hwang, C.-L.; Yoon, K. Multiple criteria decision making. Lect. Notes Econ. Math. Syst. 1981, 186, 58-191.

85. Büyüközkan, G. An integrated fuzzy multi-criteria group decision-making approach for green supplier evaluation. Int. J. Prod. Res. 2012, 50, 2892-2909. [CrossRef]

86. Yong, D. Plant location selection based on fuzzy TOPSIS. Int. J. Adv. Manuf. Technol. 2006, 28, 839-844. [CrossRef]

87. Chen, C.-T.; Lin, C.-T.; Huang, S.-F. A fuzzy approach for supplier evaluation and selection in supply chain management. Int. J. Prod. Econ. 2006, 102, 289-301. [CrossRef]

88. Kahraman, C.; Çevik, S.; Ates, N.Y.; Gülbay, M. Fuzzy multi-criteria evaluation of industrial robotic systems. Comput. Ind. Eng. 2007, 52, 414-433. [CrossRef]

89. Ekmekçioğlu, M.; Kaya, T.; Kahraman, C. Fuzzy multicriteria disposal method and site selection for municipal solid waste. Waste Manag. 2010, 30, 1729-1736. [CrossRef] [PubMed]

90. Kutlu, A.C.; Ekmekçioğlu, M. Fuzzy failure modes and effects analysis by using fuzzy TOPSIS-based fuzzy AHP. Expert Syst. Appl. 2012, 39, 61-67. [CrossRef] 
91. Kim, S.; Lee, K.; Cho, J.K.; Kim, C.O. Agent-based diffusion model for an automobile market with fuzzy TOPSIS-based product adoption process. Expert Syst. Appl. 2011, 38, 7270-7276. [CrossRef]

92. Ertuğrul, I.; Karakaşoğlu, N. Comparison of fuzzy AHP and fuzzy TOPSIS methods for facility location selection. Int. J. Adv. Manuf. Technol. 2007, 39, 783-795. [CrossRef]

93. Jia, F.; Zuluaga-Cardona, L.; Bailey, A.; Rueda, X. Sustainable supply chain management in developing countries: An analysis of the literature. J. Clean. Prod. 2018, 189, 263-278. [CrossRef]

94. Cagliano, R.; Worley, C.G.; Caniato, F.F. The challenge of sustainable innovation in agri-food supply chains. Organ. Sustain. Eff. 2016, 5, 1-30.

95. Rajesh, R.; Rajendran, C. Relating Environmental, Social, and Governance scores and sustainability performances of firms: An empirical analysis. Bus. Strat. Environ. 2020, 29, 1247-1267. [CrossRef]

96. Sabu, M.; Shaijumon, C.S.; Rajesh, R. Factors influencing the adoption of ICT tools in Kerala marine fisheries sector: An analytic hierarchy process approach. Technol. Anal. Strat. Manag. 2017, 30, 866-880. [CrossRef]

97. Govindan, K. Sustainable consumption and production in the food supply chain: A conceptual framework. Int. J. Prod. Econ. 2018, 195, 419-431. [CrossRef]

98. Rajesh, R. Sustainable supply chains in the Indian context: An integrative decision-making model. Technol. Soc. 2020, 61, 101230. [CrossRef]

99. Goswami, M.; De, A.; Habibi, M.K.K.; Daultani, Y. Examining freight performance of third-party logistics providers within the automotive industry in India: An environmental sustainability perspective. Int. J. Prod. Res. 2020, 58, 7565-7592. [CrossRef]

100. Nazam, M.; Hashim, M.; Baig, S.A.; Abrar, M.; Shabbir, R. Modeling the key barriers of knowledge management adoption in sustainable supply chain. J. Enterp. Inf. Manag. 2020, 33, 1077-1109. [CrossRef]

101. Naseer, M.; Ashfaq, M.; Hassan, S.; Abbas, A.; Razzaq, A.; Mehdi, M.; Ariyawardana, A.; Anwar, M. Critical Issues at the Upstream Level in Sustainable Supply Chain Management of Agri-Food Industries: Evidence from Pakistan's Citrus Industry. Sustainability 2019, 11, 1326. [CrossRef]

102. Choudhary, A.; De, A.; Ahmed, K.; Shankar, R. An integrated fuzzy intuitionistic sustainability assessment framework for manufacturing supply chain: A study of UK based firms. Ann. Oper. Res. 2021. [CrossRef]

103. Zhang, X.; Li, Z.; Wang, Y.; Yan, W. An Integrated Multicriteria Decision-Making Approach for Collection Modes Selection in Remanufacturing Reverse Logistics. Processes 2021, 9, 631. [CrossRef]

104. Alkahtani, M.; Choudhary, A.; De, A.; Harding, J.A. A decision support system based on ontology and data mining to improve design using warranty data. Comput. Ind. Eng. 2019, 128, 1027-1039. [CrossRef]

105. Ray, A.; De, A.; Mondal, S.; Wang, J. Selection of best buyback strategy for original equipment manufacturer and independent remanufacturer-Game theoretic approach. Int. J. Prod. Res. 2020. [CrossRef]

106. Goswami, M.; Daultani, Y.; De, A. Decision modeling and analysis in new product development considering supply chain uncertainties: A multi-functional expert based approach. Expert Syst. Appl. 2021, 166, 114016. [CrossRef]

107. De, A.; Choudhary, A.; Turkay, M.; Tiwari, M.K. Bunkering policies for a fuel bunker management problem for liner shipping networks. Eur. J. Oper. Res. 2021, 289, 927-939. [CrossRef] 